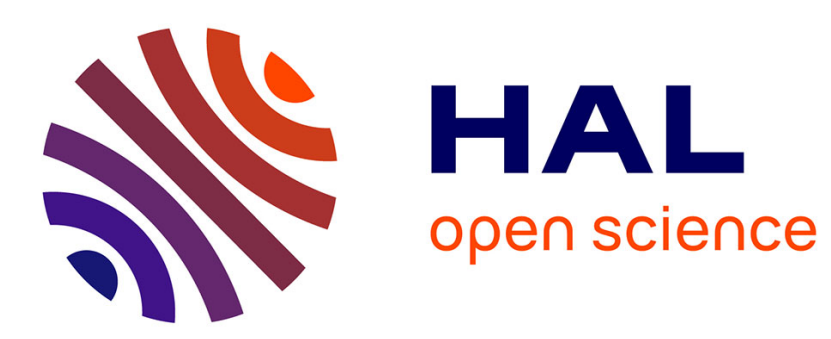

\title{
Modelling the world economy at the 2050 horizon
}

\author{
Jean Fouré, Agnès Bénassy-Quéré, Lionel Fontagné
}

\section{To cite this version:}

Jean Fouré, Agnès Bénassy-Quéré, Lionel Fontagné. Modelling the world economy at the 2050 horizon.

Economics of Transition, 2013, 21 (4), pp.617-654. 10.1111/ecot.12023 . hal-00975545

\section{HAL Id: hal-00975545 \\ https://hal.science/hal-00975545}

Submitted on 8 Apr 2014

HAL is a multi-disciplinary open access archive for the deposit and dissemination of scientific research documents, whether they are published or not. The documents may come from teaching and research institutions in France or abroad, or from public or private research centers.
L'archive ouverte pluridisciplinaire HAL, est destinée au dépôt et à la diffusion de documents scientifiques de niveau recherche, publiés ou non, émanant des établissements d'enseignement et de recherche français ou étrangers, des laboratoires publics ou privés. 


\title{
Modelling the world economy at the 2050 horizon
}

\author{
Jean Fouré ${ }^{1}$, Agnès Bénassy-Quéré2 Lionel Fontagné $^{3}$
}

Forthcoming, Economics of Transition

\begin{abstract}
Economic analysis increasingly addresses long term issues (such as global warming), which requires a dynamic baseline of the world economy. To this aim we develop a 3-factor (capital, energy, labour) macroeconometric model (MaGE - Macroeconometrics of the Global Economy) and project growth for 147 countries to 2050 . We improve on the literature by (i) accounting for the energy constraint through dynamic modelling of energy productivity, (ii) modelling female participation rates consistently with educational catch-up, (iii) departing from the assumptions of either a closed economy or full capital mobility (by applying a Feldstein-Horioka-type relationship between savings and investment rates), and (iv) offering a fully-consistent treatment of the Balassa-Samuelson effect. These innovative features have sizeable impact on projected GDPs.
\end{abstract}

JEL Classification: E23, E27, F02, F47

Key Words: $\quad$ GDP projections, long run, global economy.

\footnotetext{
1 CEPII.

${ }^{2}$ Paris School of Economics, University Paris 1 and CEPII.

${ }^{3}$ Paris School of Economics, University Paris 1, European University Institute and CEPII.
}

We are grateful to Benjamin Carton, Gilbert Cette, Yvan Decreux and Valérie Mignon for helpful advice, and to the participants in the joint Bank de France-CEPII-INSEE-French Treasury seminar, held 19 May 2010, for their remarks on an early draft. All errors remain ours. 


\section{INTRODUCTION}

Economic analysis increasingly addresses long-term issues, such as natural resource depletion, global warming, or energy scarcity. To do so, relying on a baseline of the world economy is generally a prerequisite, hence the need to project production factors and economic growth based on a sound and transparent theoretical and econometric framework. Surprisingly, with some exceptions (Duval and de la Maisonneuve, 2010, Johansson et al., 2013), the economic literature does not care much about these issues. This contrasts with the large interest for long term projections in the business community and in international organizations. The reasons for academic prudence vis-à-vis long-term projections are understandable. First, long-term projections rarely prove accurate and are likely to be heavily disrupted by geopolitical events that can hardly be expected. Second, a consistent projection of the world economy imposes applying the same methodology to each country, which is unlikely to fit the reality. Still, the scarcity of solidly-grounded, long-term projection exercises may oblige downstream analysts to rely on some form of extrapolation, which is likely to generate misleading orders of magnitude.

Our argument then is that a sound and transparent macroeconometric framework, combined with publicly available data, code and projections, will provide a useful basis both for the necessary debate on the evolution of the global economy in the long run, and for downstream analyses. This paper aims at providing such framework through the MaGE (Macroeconometrics of the Global Economy) model. Four major improvements on the literature are introduced: (i) we explicitly tackle energy use and efficiency, through relying on a nested CES structure à la van der Werf (2008) and Markandya and

\footnotetext{
4 This interest is visible in the success encountered by partially documented projections (e.g. Wilson and Purushothaman (2003), "Dreaming with BRICs: The path to 2050", and Wilson et al. (2011), "The BRICs 10 Years On: Halfway Through The Great Transformation" in Goldman Sachs Global Economics Papers; Ward (2011), "The World in 2050: Quantifying the Shift in Global Economy”, HSBC Global Economics, January; Hawksworth and Anmol (2011), "The World in 2050-The Accelerating Shift of Global Economic Power: Challenges and Opportunities". Price Waterhouse Coopers, January.). An effort to rely on firm theoretical foundations is provided by Poncet (2006), 'The Long Term Growth Prospects of the World Economy: Horizon 2050', CEPII Working Paper 16, and by the continuous efforts of the OECD (see, e.g., Chapter of the OECD Economic Outlook, 2012/1).
} 
Pedrosso-Galinato (2007), and modelling a U-shape relationship between economic development an energy productivity; (ii) we model female participation to the labour market and education in a consistent way; (iii) we relax the closed economy assumption hardly adapted to a globalised economy when capital accumulation is at stake; (iv) we finally model valuation effects instead of sticking to volumes, using a Balassa-Samuelson effect derived from the specific production function.

After setting the theoretical framework, we propose careful panel econometric estimations over 19802009 for 147 countries. We then perform recursive projections at the 2050 horizon, starting in 2013 when we assume that output gaps related to the 2008-09 global crisis have been closed. Finally, we quantify the impact of our four innovative features, as well as some modeling assumptions, on projected GDPs.

In the central scenario, China and India grow 9-fold between 2010 and 2050 at constant relative prices. Over the same period, the US and EU economies would inflate by around 90\%. Adjusting for relative price variations results in a 20-fold increase in China's GDP and a 17-fold increase for India. Assumptions on energy, female participation and international capital mobility are shown to have a very significant impact for some countries or areas, with sometimes two-digit variations in GDP. Conversely, the impact is relatively limited at the global level (never above 2.5 percent of global GDP at the 2050 horizon).

The remainder of the paper is organised as follows. The theoretical framework is set up in Section 1 . Section 2 describes the data and econometric estimations of behavioural relations. Section 3 reports projections up to 2050. Section 4 shows how our methodological innovations impact long-run projections. Section 5 concludes.

\footnotetext{
${ }^{5}$ The detailed projections are available at www.cepii.fr.
} 


\section{INNOVATIVE FEATURES OF OUR ANALYTICAL FRAMEWORK}

Conditional on institutions, long-term growth is determined by labour force, capital accumulation and TFP growth. Energy is not usually considered a separate factor for GDP projections. Hence, its contribution to growth is most often embodied in TFP growth. This is not satisfactory for two reasons. First, for most economies, energy scarcity and subsequent price increase will likely constitute a major constraint to GDP growth in the future - a constraint that can be partially circumvented by progress in energy efficiency; second, for oil producers, GDP growth is less dependent on labour force increase, capital accumulation, and TFP growth than on oil-price variations. In this section, we first present how energy is incorporated in the model. We then describe our theoretical improvements on the literature concerning the labour force, capital accumulation and valuation effects. The empirical strategy is detailed in the next section.

\subsection{Energy}

We rely on a nested Constant Elasticity of Substitution (CES) production function where capital can be substituted for labour with a unitary elasticity (Cobb-Douglas assumption) whereas the capitallabour bundle can substitute less easily for the scarcity of energy. The use of such nested CES production function was proposed by David and van de Klundert (1965) to encompass different kinds of input-augmenting technical change, and was employed also in van der Werf (2008), Markandya and Pedrosso-Galinato (2007) as well as in Chateau et al. (2012). Consistently, real GDP for country $i$ at time $t$ can be written as:

$Y_{i, t}=\left[\left(A_{i, t} \cdot K_{i, t}^{\alpha} L_{i, t}^{1-\alpha}\right)^{\frac{\sigma-1}{\sigma}}+\left(B_{i, t} \cdot E_{i, t}\right)^{\frac{\sigma-1}{\sigma}}\right]^{\frac{\sigma}{\sigma-1}}, 0<\alpha<1, \quad 0<\sigma<1$

where $Y_{i, t}$ denotes the volume of GDP, and $E_{i, t}, K_{i, t}$ and $L_{i, t}$ represent energy, capital and labour, respectively. In oil-producing countries, $Y_{i, t}$ is taken net of the oil rent in order to avoid a biased measure of productivity. $A_{i, t}$ is the usual TFP term, which in this case is the efficiency of the 
combination of labour and capital, and $B_{i, t}$ is a measure of energy productivity. For exposition purpose, we will drop country and time subscripts for the remainder of this section. ${ }^{6}$

Oil production is assumed to be a pure rent: the volume of production is constant, but its real value (in terms of the GDP deflator) increases depending on the relative price of oil. The oil rent is ultimately added to the non-oil GDP. ${ }^{7}$

At each period, the optimal level of energy consumption $E$ depends both on energy productivity $B$ and on the relative price of energy $p_{\mathrm{E}}$. Maximizing the representative firm's profit given the production function (1.1) yields:

$E=Y \frac{B^{\sigma-1}}{p_{E}^{\sigma}}$

Energy productivity $B$ is distinct from TFP $A$ which is calculated as a Solow-like residual. Over the past, B is recovered by inverting Equation (1.2). Looking forward, it is projected as a U-shaped function of economic development (see Section 2.1).

The elasticity of substitution between energy and the capital-labor bundle, $\sigma$, is calibrated based on the range of existing estimates. ${ }^{8}$ Specifically, we choose $\sigma=0.2$, which allows us to recover plausible values of $B$ over the 1980-2008 period. ${ }^{9}$

\footnotetext{
${ }^{6}$ Estimating the parameters of Equation (1.1) is beyond the scope of this paper. As detailed by Griliches and Mairesse (1995), such an estimation raises a number of econometric difficulties. Here we select $\alpha=0.3$ which is a standard value of the literature. Mankiw, Romer and Weil (1992) find this value when controlling the estimation for human capital. Since we also control for human capital, although in a different way, we believe $\alpha=0.3$ to be a relatively safe assumption. The calibration of $\sigma$ is discussed below.

7 Due to the lack of data, energy rents are here limited to oil rents. This simplification is benign since oil dominates international exchanges of non-renewable energies. In the following, we indifferently use the terms "energy" and "oil". ${ }_{9}^{8}$ See Van der Werf (2008), who finds estimates ranging from 0.17 to 0.69 for 12 OECD countries over 1978-1996.

9 Past values of $B$ are an inverse function of energy price, and the more so the higher the chosen elasticity. For $\sigma>$ 0.2 , the past evolution of energy productivity $B$ mirrors that of the energy price, with marked short-term volatility. To measure the sensitivity of our results to the value of this elasticity, we have performed the whole projection exercise for values of $\sigma$ ranging from 0.15 to 0.40 . Although the value of the elasticity makes a difference for fast-growing countries, the ranking of the major countries stays unaffected at the 2050 horizon. Results are available upon request.
} 


\subsection{Female participation}

We rely on United Nations projections of the working-age population (medium fertility projection), on which we apply an original modeling of participation rates. Existing projections of participation rates by ILO have two limitations. First, they do not extend beyond 2020. Second, they rely on a conservative modeling of female participation rates, which is questionable, given the ongoing education convergence across the world. Surprisingly, educational catch up is sometimes considered as a factor fueling TFP growth, but its impact on female participation to the labor market is disregarded. We believe that failing to account for the impact of education on female participation can lead to biased projections of TFP, in particular for many catching-up countries. The modeling of participation rates simply relies on education catch up by cohort, which is also used to project TFP growth (see Section 2 for details).

\subsection{Capital mobility}

Capital accumulates through a standard, permanent-inventory process depending on gross capital formation and (constant) capital depreciation. The existing literature projects the latter either through a closed-economy assumption (hence investment is equal to savings on a country-by-country basis, see Poncet, 2006) or by assuming a convergence and/or stabilization process of the capital-to-GDP ratio (Duval and de la Maisonneuve, 2010; OECD, 2012). In contrast, we argue that large, lasting currentaccount imbalances as was observed in the 2000s can no longer be neglected when capital accumulation is at stake, although savings and investments are closely related, as initially noted by Feldstein and Horioka (1980). Consistently, we rely on an estimated, error-correction relationship between saving and investment rates. Gross saving rates are derived from an econometric equation based on the life-cycle hypothesis. ${ }^{10}$

\footnotetext{
${ }^{10}$ We do not account here for any trend variation of the price of investment relative to the GDP deflator. The reason is the fragility of existing databases on this issue.
} 


\subsection{Valuation effects}

GDP projections in volume are useful to address reshaping of global production, demand for production factors and carbon emissions. However, they do not provide an indication of the weight of each country in terms of global purchasing or financial power. Hence we also need to project relative prices - a difficult task given the inconclusiveness of the literature on real exchange-rate determination, especially when a large number of currencies from both advanced and developed economies is at stake. Here we rely on the Balassa-Samuelson effect, which has been shown a relatively robust relationship in the literature. ${ }^{11}$ According to this theory, in each country the price of non-tradable goods tends to increase relative to that of tradable ones along economic catch-up, triggering real exchange-rate appreciation. Here we need to adapt the standard Balassa-Samuelson setup $^{12}$ to our three-factor production function.

We assume that every national economy has two sectors: traded goods (denoted by $T$ ), and non-traded goods (denoted by $N$ ). Both sectors have the same production functions as in Equation (1.1). However, their productivities differ in terms of both primary factors and energy. For each sector $S(S=T, N)$, we have:

$Y_{S}=\left[\left(A_{S} Q_{S}\right)^{\frac{\sigma-1}{\sigma}}+\left(B_{S} E_{S}\right)^{\frac{\sigma-1}{\sigma}}\right]^{\frac{\sigma}{\sigma-1}}$

where $Q_{s}$ denotes the Cobb-Douglas combination of capital and labour $\left(Q_{s}=K_{s}{ }^{\alpha} L_{s}{ }^{1-\alpha}\right)$. Let $p$ denote the relative price of non-tradables to tradables: $p=P_{N} / P_{T}$. Writing the first-order conditions and assuming that the share of energy in income (denoted by $\mu$ ) is the same in the two sectors, we get: ${ }^{13}$

$\dot{p}=(1-\mu)\left(\dot{A}_{T}-\dot{A}_{N}\right)+\mu\left(\dot{B}_{T}-\dot{B}_{N}\right)$

\footnotetext{
${ }^{11}$ Rogoff (1996) shows the Balassa-Samuelson to be relatively robust when contrasting advanced and developing countries.

${ }_{13}^{12}$ See, e.g., De Gregorio, Giovannini and Wolf (1994).

${ }^{13}$ The proof is available from the authors.
} 
where $\dot{X}=\frac{d X}{X d t}$. Assuming a Cobb-Douglas consumption bundle $\left(C=Y_{T}^{\gamma_{c}} Y_{N}^{1-\gamma_{c}} 0<\gamma_{c}<1\right)$, the real consumer price index, in terms of the tradable good can be written as: $P=p^{1-\gamma_{c}}$. Ignoring productivity growth in the non-traded sector, and assuming that the share of traded goods in output is $\gamma_{Y}$ (such that $\dot{A}=\gamma_{Y} \dot{A}_{T}$ ), we get:

$\dot{P}=\left(1-\gamma_{c}\right) \dot{p}=\frac{1-\gamma_{c}}{\gamma_{Y}}(\mu \dot{B}+(1-\mu) \dot{A})$

Finally, denoting by RER the real exchange rate (i.e. the relative price of the home consumption basket to the foreign one) and by a star the foreign country, we get:

$R \dot{E} R=\frac{1-\gamma_{c}}{\gamma_{Y}}[(1-\mu) \dot{A}+\mu \dot{B}]-\frac{1-\gamma_{c}^{*}}{\gamma_{Y^{*}}}\left[\left(1-\mu^{*}\right) \dot{A}^{*}+\mu^{*} \dot{B}^{*}\right]$

Hence, real-exchange rate appreciation is based on aggregate TFP and energy productivity catch-up, and the effect is magnified by a higher share of non-tradable goods both in the consumption basket and in output, which themselves can move along economic development.

\section{ECONOMETRIC ESTIMATIONS}

In order to recover the variables mentioned in Section 1, we need to carefully estimate a number of econometric relationships. In this section we focus on the distinctive features of the MaGE model, namely energy, female participation, capital accumulation and valuation effects. Data sources are listed in Appendix A and additional estimations (in particular education catch up and TFP growth) are presented in Appendix B.

\subsection{Energy}

As already mentioned, energy consumption is modelled based on the optimal behaviour of the representative firm given energy price and energy productivity (see Equation (1.2)). 
We use the oil price as a proxy for the price of energy. It is forecasted to 2035 by the Energy Information Administration (EIA). ${ }^{14}$ For 2035 to 2050, the price of energy is set to increase at a constant rate equal to its average growth rate over the 2030-2035 period.

We model the growth rate of energy productivity as a two-dimensional catch-up process that results in a U-shaped relationship between economic development and energy productivity, relying on two different convergence processes: one to the development frontier, and the other one to the energyproductivity frontier. ${ }^{15}$ Consistently, we estimate the following relationship on five-year intervals:

$\ln \left(\frac{B_{i, t}}{B_{i, t-1}}\right)=\mu_{0, i}+\mu_{1} \ln \left(\frac{B_{i, t-1}}{B_{t-1}^{*}}\right)+\mu_{2} \ln \left(\frac{y_{i, t-1}}{y_{U S, t-1}}\right)+\varepsilon_{i, t}$

where $B_{\mathrm{t}-1}^{*}$ denotes the energy-productivity frontier. ${ }^{16}$ Over 1980-2009, time-series for energy productivity are recovered based on Equation (1.2), given observed GDP, energy consumption and the real oil price.

The estimation results are presented in Table 1. For both OECD and non-OECD countries, the distance to the most efficient countries has the expected, negative impact on energy productivity growth: the further from the frontier (the lower $B / B^{*}$ ) the higher energy productivity growth. For nonOECD countries, this effect is compounded by a positive, significant impact of the distance to US GDP per capita on energy productivity growth: the closer to US GDP per capita (the higher $y / y_{\mathrm{US}}$ ), the higher energy productivity growth. Hence, data support the idea of a double-catch-up process. In the following, we retain the OECD/non-OECD grouping for energy productivity.

\footnotetext{
${ }^{14}$ http://www.eia.gov/forecasts/ieo/liquid_fuels.cfm, medium scenario.

15 Low income countries are energy-efficient because their economies are based on the primary sector. As countries develop, the weight of industry, which consumes more energy, increases, reducing aggregate productivity; after industrial transition is completed, technological efficiency tends to improve.

${ }^{16}$ We define the energy-productivity frontier based on the mean of the four most energy productive countries (the United Kingdom, Japan, Germany and France), leaving Switzerland aside due to its specificities (small landlocked country based mainly on services).
} 
Table 1 - Energy productivity growth: estimation results

\begin{tabular}{lccc}
\hline & $(1)$ & $(2)$ & $(3)$ \\
& OECD & OECD & Non-OECD \\
\hline $\begin{array}{l}\text { Lagged distance to efficiency } \\
\text { leader }\end{array}$ & $-0.058^{* * *}$ & $-0.059^{* * *}$ & $-0.090^{* * *}$ \\
& $(0.010)$ & $(0.010)$ & $(0.006)$ \\
Lagged distance to US GDP per & -0.005 & & \\
capita & $(0.019)$ & & $0.013^{*}$ \\
& & & $(0.007)$ \\
Constant & $-0.019 * *$ & $-0.017 * * *$ & $-0.113^{* * *}$ \\
& $(0.009)$ & $(0.004)$ & $(0.020)$ \\
\hline $\mathrm{N}$ & 163 & 163 & 777 \\
Groups & 25 & 25 & 137 \\
F-stat & 1.949 & 2.479 & 2.715 \\
\hline N & & &
\end{tabular}

Note: Standard errors in parentheses. $* \mathrm{p}<0.1, * * \mathrm{p}<0.05, * * * \mathrm{p}<0.01$. Five years intervals Source: own calculations.

\subsection{Female participation}

Female participation rates by age group are projected from 2010 to 2050 based on an econometric relation with education. This choice allows us to account for the anticipated rise in female participation rates for a number of developing countries, in line with projected catch-up in terms of education.

The literature on female participation points fertility, urbanization and education as key factors of female participation (see, e.g., Bloom et al. (2009)). However, the estimation of participation rates encounters a reverse-causality problem. In particular, fertility rates depend on activity. Bloom et al. circumvent this problem by instrumenting fertility with abortion laws. However abortion laws do not change frequently, so they can be embodied in country fixed effects. Here, we estimate the following logistic equation on our 5-year-interval education data: ${ }^{18}$

\footnotetext{
${ }^{17}$ For men, we use ILO participation rates up to 2020. From 2021 to 2050, male participation rates are projected based on ILO's methodology. Specifically, the participation rate of males of age $a$ in country $i$ at time $t$ is $l_{a, i, t}^{M}$ such as: $l_{a, i, t}^{M}=\underline{l}_{a, i}^{M}+\frac{\bar{l}_{a, i}^{M}-\underline{l}_{a, i}^{M}}{1+e^{\alpha} a, i+\beta_{a, i} \cdot}$, where $\underline{l}_{a, i}^{M}$ and $\bar{l}_{a, i}^{M}$ are age and country-specific minimum and maximum participation rates, and $\alpha_{\mathrm{a}, \mathrm{i}}$ and $\beta_{\alpha, \mathrm{i}}$ are the parameters of the process, which are recovered through a reverse engineering method.

${ }^{18}$ In a preliminary step, we have checked that education accounts for a larger share of the variance, especially the time variance, of female labour participation rates, as compared to other factors investigated by Bloom et al. (2009): fertility rates, infant mortality and capital per capita. The results are available from the authors.
} 
$\ln \left(\frac{l_{a, i, t}^{F}}{1-l_{a, i, t}^{F}}\right)=\phi_{a, i}^{0}+\phi_{a}^{1} h_{a, i, t}^{2}+\phi_{a}^{2} h_{a, i, t}^{3}+\varepsilon_{a, i, t}$

where, $l_{a, i, t}^{F}$ represents the participation rate of females of age $a$ in country $i$ at time $t, h_{a, i, t}^{2}$ is the proportion of age-group $a$ (of both genders) ${ }^{19}$ in year $t$ that has at least a secondary diploma, $h_{a, i, t}^{3}$ is the proportion holding a tertiary diploma, $\phi_{a, i}^{0}$ is a country-age group fixed effect and $\varepsilon_{a, i, t}$ is the residual of the equation.

Equation (2.2) is estimated for each age group separately, for 140 countries over $1980-2010 .^{20}$ Education is captured through school attainment by age group, based on the Barro and Lee (2010) database. The results are reported in Appendix B. We find a positive and significant impact of both levels of education on participation between 20 and 59 years old. Conversely, we find a negative impact before 20 (secondary and tertiary education), between 20 and 24 (tertiary education) and after 60 (secondary education). The negative impact of education on participation of the 15-19 and 20-24 groups can easily be explained by the lengthening of studies. As for the negative impact of education on participation of elder groups, it may be related to the ability of educated workers to retire, in contrast with non-educated ones, especially in developing countries. It can be inferred from the econometric results that, for a 5-year age group between 20 and 59 starting from a $30 \%$ female participation rate, a move from 60 to 100 percent secondary school attainment would raise the female participation rate by 4 to 12 percentage points, depending on the age group.

The way education attainment by age group is projected is also detailed in Appendix B. Education attainment is modeled separately for primary, secondary and tertiary education. In each case, we

\footnotetext{
${ }^{19}$ Bloom et al. (2009) show the female participation rate to depend on both genders' education attainment.

${ }^{20}$ For the remaining seven countries, we have to rely on the respective regional means, due to missing data.
} 
assume a simple catch-up process relative to the leader's level, ${ }^{21}$ with different speeds across regions of the world. As for the leader, its education level is modeled through an estimated logistic function.

Secondary and tertiary education also play a key role for TFP growth. Following Vandenbussche et al. (2006), we model TFP growth as the combination between a pure catch-up effect, a pure education effect, and an interaction term between education and catch up using instrumental variables to deal with endogeneity (see Appendix B).

\subsection{Capital mobility}

As already mentioned, capital accumulation is modelled based on an assumption of imperfect capital mobility. We first model the savings rate relying on Masson, Bayoumi and Samiei's (1998) life-cycle approach (see Appendix B). We then estimate an error-correction model for the relationship between the savings rate and the investment rate, à la Feldstein-Horioka.

We start with the standard, Feldstein-Horioka type estimation (see Herwartz and Xu, 2010):

$$
\left(\frac{I}{Y}\right)_{i, t}=\alpha_{i}+\beta\left(\frac{S}{Y}\right)_{i, t}+u_{i, t}
$$

where $(I / Y)$ denotes the (yearly) investment-to-GDP ratio. ${ }^{23}$ The lower $\beta$, the higher capital mobility. We follow Chakrabarti (2006) and divide our sample into OECD and non-OECD countries, which can be justified by large differences in financial openness between the two types of countries. Preliminary panel unit root tests suggest that both saving and investment rates are non-stationary. We therefore perform panel-cointegration tests based on Westerlund (2007) and Pedroni (1999). Although less frequent in the literature than Pedroni's, Westerlund tests do not rely on an assumption of

${ }^{21}$ Several countries can appear the leader level at least for one age group during a sub-period. The main primary education leaders are Austria, Japan, France and Switzerland. The main secondary education leaders are the United States, Australia, Norway and New Zealand. The main tertiary education leaders are the United States, Australia, New Zealand and Russia.

${ }^{22}$ In 1980, Feldstein and Horioka published a famous regression evidencing close relationship between the investment rate and the savings rate at the country level, despite nascent financial globalisation. Since then, a number of scholars have re-run their regression and found looser relationships (see, e.g., Blanchard and Giavazzi 2002).

${ }^{23}$ We model the relationship between gross savings and gross capital formation (GCF). When cumulating fixed capital, we then correct GCF for the median of the distribution of average inventory changes (0.87\% of GDP). 
independence. The tests reject the null of no cointegration (at the $1 \%$ level for OECD countries, and at the 5\% level for the non-OECD group). The results of the Pedroni tests are more mixed, but still tend to favour cointegration (see Appendix B).

The corresponding error-correction model is then estimated using the Engle and Granger two-step method (see e.g. Coiteux and Olivier, 2000, or Herwartz and Xu, 2009). First, the long-run relationship (Equation 2.3) is estimated in panel, leading to estimates of $\alpha_{i}$ and $\beta$. This allows us to estimate the following relation with yearly data:

$\Delta\left(\frac{I}{Y}\right)_{i, t}=v_{i}^{0}+v^{1}\left(\left(\frac{I}{Y}\right)_{i, t-1}-\hat{\alpha}_{i}-\hat{\beta}\left(\frac{S}{Y}\right)_{i, t}\right)+v^{2} \Delta\left(\frac{S}{Y}\right)_{i, t}+\varepsilon_{i, t}$

where $\Delta$ is the first-difference operator, $\hat{\alpha}_{i}$ and $\hat{\beta}$ are estimates from equation (2.3), and $v^{1}$ is the speed of adjustment towards the long-run relationship.

Some authors estimate this relationship on a country-by-country basis (see Pelgrin and Schich, 2004 for a review). However, the coefficients obtained can be insignificant, especially among developing countries (Mamingi, 1997). Using panel data estimation techniques increases the degrees of freedom for the estimation.

Table 2 reports the cointegration vector for each panel of countries (OECD, and non-OECD). The $\beta$ coefficient obtained for the OECD panel $(0.685)$ is in line with the literature. However, that obtained for the developing countries it is significantly lower, and lower than the coefficients estimated by Chakrabarti (2006): despite lower de jure capital mobility, emerging and developing countries seem to display higher de facto capital mobility than advanced ones, which can be related to relatively large current-account imbalances. $^{24}$

\footnotetext{
${ }^{24}$ Over 1980-2008, the absolute value of current accounts for the non-OECD countries was 9.7\% of GDP on average, compared to only $4 \%$ for the OECD countries. Calculation based on the IMF, World Economic Outlook database, April 2010. In addition, our developing countries sample is larger than the sample in Chakrabarti (2006) and our results for the non-OECD group might hide some heterogeneity. In the following, we keep different $\beta$ coefficients for OECD and non-OECD countries. In results not reported here, we checked that the sensitivity of our results to this assumption was limited. See also Section 4.4.
} 
Table 2 - The Feldstein-Horioka relation, cointegration vector

\begin{tabular}{lcc} 
& $(1)$ & $(2)$ \\
& OECD & Non-OECD \\
\hline Savings rate & $0.685^{* * *}$ & $0.205^{* * *}$ \\
& $(0.018)$ & $(0.010)$ \\
& & \\
Constant & $0.075^{* * *}$ & $0.186^{* * *}$ \\
& $(0.0045)$ & $(0.002)$ \\
\hline $\mathrm{R}-\mathrm{sq}$ & 0.547 & 0.0819 \\
$\mathrm{~N}$ & 1232 & 5028 \\
Groups & 30 & 139 \\
F-stat & 36.96 & 24.78 \\
\hline
\end{tabular}

Standard errors in parentheses

$* \mathrm{p}<0.1, * * \mathrm{p}<0.05, * * * \mathrm{p}<0.01$

Note: yearly data. Source: own calculations.

The results of the error-correction models (ECM) are presented in Table 3. The Fisher test cannot reject the null hypothesis that all fixed effects are equal to zero. Hence, the ECMs are finally estimated with neither fixed effects nor a constant. The error correction coefficient $v^{1}$ is found to be significant and negative for both groups of countries, with similar magnitude: each year, $20-25 \%$ of the discrepancy between the lagged investment rate and its (lagged) long-run value is erased. However, the impact of the short-term dynamics of the savings rate on the investment rate is higher for the OECD than in non-OECD group of countries.

Table 3 - Error correction model

\begin{tabular}{lcccc}
\hline \multicolumn{1}{c}{$(1)$} & $(2)$ & $(3)$ & $(4)$ \\
& OECD & OECD & Non-OECD & Non-OECD \\
\hline Delta Savings rate & $0.769^{* * *}$ & $0.767 * * *$ & $0.175^{* * *}$ & $0.175^{* * *}$ \\
& $(0.021)$ & $(0.021)$ & $(0.010)$ & $(0.010)$ \\
& & & & \\
Error correction term & $-0.210^{* * *}$ & $-0.212^{* * *}$ & $-0.243 * * *$ & $-0.245^{* * *}$ \\
& $(0.018)$ & $(0.018)$ & $(0.009)$ & $(0.009)$ \\
& & & & \\
Constant & -0.0006 & & 0.0007 & \\
& $(0.0006)$ & & $(0.0006)$ & \\
\hline R-sq & 0.564 & 0.563 & 0.172 & 0.172 \\
N & 1202 & 1202 & 4876 & 4876 \\
Groups & 30 & & 139 & \\
F-stat & 0.197 & & 0.194 & \\
\hline Note: Standard errors in parentheses; $* \mathrm{p}<0.1, * * \mathrm{p}<0.05, * * * \mathrm{p}<0.01 ;$ Yearly data. \\
Source: own calculations.
\end{tabular}


Finally, we are left with the $\mathrm{n}^{\text {th }}$ country problem: with $n$ countries in the world, there are only $n-1$ independent savings-investment imbalances. In other words, savings-investment imbalances should sum to zero across our 147 countries (assuming that the weight is negligible for the remaining world countries). Rather than dropping the savings and investment equations for one country that might be considered as the 'rest of the world', we choose to distribute the discrepancy across all 147 countries, proportional to their share in world investments. Capital stocks are ultimately recovered through a permanent-inventory process with a 6 percent depreciation rate.

\subsection{Valuation effects}

As shown in Section 1, the evolution of real exchange rates for each country compared to the United States can be expressed as a simple function of capital-labor and energy productivity catch up, with proportionality factors that depend on the share of tradable goods in both GDP and consumption, and on the distribution of income across production factors in each country and in the United States. The share of energy in income is derived from the projection itself. As for the shares of tradables, we proceed step by step. We first calculate, for each sector, the export-to-production ratio. ${ }^{25}$ We then consider as tradable any sector displaying an export share exceeding $8 \%$, which corresponds to the gap in the observed bimodal distribution of export shares. ${ }^{26}$ Having identified traded and non-traded sectors, we then calculate the share of the former in each country's production and consumption. Finally, in order to account for changes in the shares of tradables in the economy along the catch-up process, we estimate two cross-section, logistic relationships between the share of tradables in consumption (resp. production) in country $i, \gamma_{\mathrm{i}}$, and GDP per capita in purchasing power parity, $Y_{i} / P_{\text {op }}$ :

\footnotetext{
${ }^{25}$ We use the sectoral classification of the Global Trade Analysis Project (Purdue University), which comprises 57 sectors.

${ }^{26}$ This threshold classifies services and a few agricultural sectors (cattle, paddy rice, raw milk and sugar cane) as nontraded.
} 
$\ln \left(\frac{\gamma_{i}}{1-\gamma_{i}}\right)=\kappa_{0}+\kappa_{1} \ln \left(\frac{Y_{i}}{\text { Pop }_{i}}\right)+\epsilon_{i}$

We exclude from the sample those countries that appear as outliers, such as oil-producing countries and financial centres (which both have high shares of tradable goods and very high GDP per capita). ${ }^{27}$ The results of the estimations are reported in Table 4. A rise in GDP per capita tends to reduce the share of tradables both in consumption and in production, and slightly more for the former than for the latter. $^{28}$

Table 4 - Share of traded goods, estimation results

\begin{tabular}{lcc}
\hline & $(1)$ & $(2)$ \\
& Consumption & Production \\
\hline Log of GDP per capita & $-0.172^{* * *}$ & $-0.101^{* * *}$ \\
& $(0.036)$ & $(0.022)$ \\
& & \\
Constant & $0.998^{* * *}$ & $0.813^{* * *}$ \\
& $(0.308)$ & $(0.190)$ \\
\hline Obs & 165 & 165 \\
$\mathrm{R}-\mathrm{sq}$ & 0.126 & 0.113 \\
\hline Standard errors in parentheses; $* \mathrm{p}<0.1, * * \mathrm{p}<0.05, * * * \mathrm{p}<0.01$ \\
Source: own calculations.
\end{tabular}

We can then project bilateral real exchange rates against the United States based on Equation (1.7), where the real exchange rate appreciates depending on relative TFP and energy productivity growth compared to the United States, and on the share of non-tradables in the economy. ${ }^{29}$

\section{Projected LONG-TERM GROWTH}

Using MaGE allows us to make long-run economic projections for 147 countries. Being a supply-side model, MaGE is unable to project any change in the output gap. Thus, the starting point for the projections should be a year when GDP was at its potential level in most countries. We then have to

\footnotetext{
${ }^{27}$ Namely, we drop Qatar, Luxemburg, United Arab Emirates, Kuweit, Singapore, Bahrein, Norway and Iceland.

${ }^{28}$ We smooth out the shares of tradables in consumption and production in order to avoid a jump at the beginning of the projection.

${ }^{29}$ The share of energy in income (GDP) is derived from the simulation itself. In oil-exporting countries, the real exchange-rate appreciation along economic catch-up may result from a Dutch disease rather than TFP growth in the tradable, non-oil sector. We are not able to distinguish the two effects in our model.
} 
deal with the 2008-2009 global crisis. Starting our projection in 2007 would encounter the risk of overestimating GDPs because it would neglect the collapse in investment during the crisis. Additionally, the output gap may retrospectively appear largely positive the year before the crisis hit. We prefer to use IMF forecasts (Autumn, 2011) to project GDP up to 2012, and adjust TFP at this date so as to match with our projections of production factors at this horizon. We thus use MaGE to perform GDP projections for 2013 to 2050 . This methodology may overstate the drop in TFP during the crisis since we are unable to account for the temporary fall in investment rates and the rise in unemployment, whose effects will extend beyond 2012. However, this feature is benign since our interest is in GDP, not employment or TFP and we focus on the long term.

From 2013 to 2050, we use UN projections of population by age group, ILO male activity rate (up to 2020) and the EIA projection of the oil price (which we extrapolate from 2036 to 2050) as the only exogenous variables of our simulation. All other variables are projected endogenously by MaGE.

\subsection{Reference period}

Our projections rely on the econometric estimations presented in Section 3. One difficulty however is that, when included in the estimations, fixed effects are not always significant. Hence, it may be unwise to rely on fragile fixed effects that may considerably affect the results, especially over a long horizon. To circumvent this problem, our projections are based on differences from a (shorter) reference period, which will more likely resemble the starting point of our projection in terms of institutions.

Let $Z_{i, t}$ denote a projected variable for country $i$ in year $t, X_{i, t}^{k}(k=1$ to $K)$ its explanatory variables, $\alpha_{k}$ the corresponding coefficients. Denoting by $\alpha_{0, i}$ the country fixed effects, we have:

\footnotetext{
${ }^{30}$ Duval and de la Maisonneuve (2010) uses a similar strategy to deal with the crisis period.
} 
$Z_{i, t}=\alpha_{0, i}+\sum_{k=1}^{K} \alpha_{k} X_{i, t}^{k}+\epsilon_{i, t}$

where $\epsilon_{i, t}$ are the residuals of the estimation. Denoting by $\bar{Z}_{i}$ the average value of $Z_{i, t}$ over a reference period, and by $\bar{X}_{i}^{k}$ the average value of $X_{i, t}^{k}$ over the same period, we have:

$Z_{i, t}=\bar{Z}_{i}+\sum_{k=1}^{K} \alpha_{k}\left(X_{i, t}^{k}-\bar{X}_{i, t}^{k}\right)+\left(\epsilon_{i, t}-\bar{\epsilon}_{i}\right)$

Equation (3.2) no longer relies on our estimates of country- (or region-)specific constants; it rather explains the deviations of $Z$ from its average during the reference period. Here we choose 1995-2008 as the reference period. This period corresponds to the post-transition era. It follows important structural reforms in China and corresponds to the emergence of a number of large, developing economies. ${ }^{31}$ The error term is dropped in the projection exercise.

When the estimation is run on 5-year intervals (education, female participation, TFP, energy productivity), projections are turned into yearly data by considering constant growth rates over each 5year window. ${ }^{32}$ When estimations are conducted on 5-year averages (savings rate), we build yearly data by applying the estimated relation to each year, successively.

\subsection{Key inputs}

We can now illustrate the role of our four main innovations relative to the literature: energy, female participation, imperfect capital mobility and valuation effects.

\footnotetext{
31 Alternatively, we could have chosen the entire 1980-2008 period as the reference. This would have been equivalent to working with fixed effects. The non-significance of some fixed effects can then be easily understood given the heterogeneity of this long period for a large number of countries. We could also have tried to make the fixed effects endogenous, e.g. if institutions are supposed to converge over time. However it is difficult to set a priori which institution is going to dominate the world by 2050, therefore we do not include convergence of institutions in our central scenario, but develop a sensitivity analysis in section 4.4 .

TFP growth for leaders is set to 0.995 percent per year (the leader group's average over 1995-2008). We allow for a smooth transition between catching-up and leader status, starting when the country reaches 90 percent of the frontier level. Financial centres such as Luxembourg, Switzerland or Iceland are excluded from the leaders group. Their TFP is then simply assumed to grow at the same pace as that of the frontier.

${ }^{33}$ The projection of each production factor for all the 147 countries up to 2050 is available at www.cepii.fr.
} 
Our projections of energy productivity are reported in Figure 1 for selected countries and areas. The energy productivity of frontier countries (the UK, Japan, Germany and France) is assumed to increase at a constant exogenous rate $(+0.25$ percent per year, which corresponds to their average growth rate over 1995-2008). The remaining countries tend to catch up to this frontier, except in Sub-Saharan Africa where industrialization tends to hinder the catch-up process.

Figure 1 - Energy productivity, 1980-2050, OECD and BRICs (2005 USD per barrel)

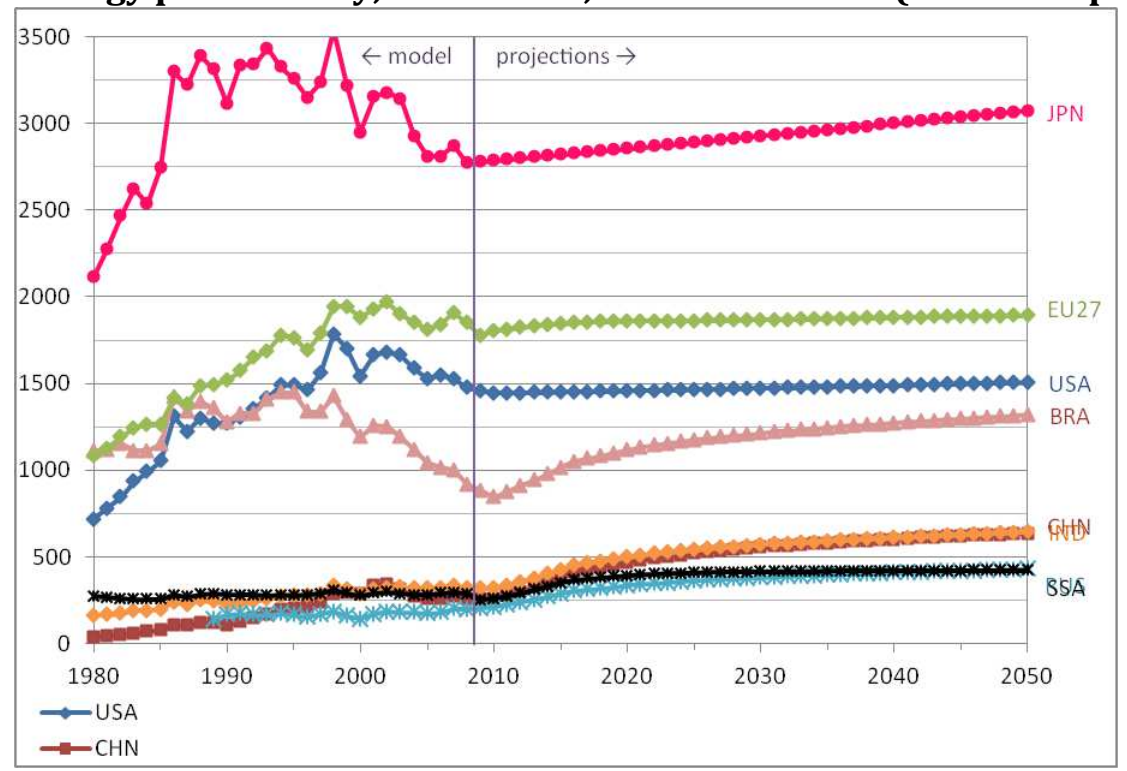

Notations: $\mathrm{CHN}=$ People's Republic of China; IND=India; RUS=Russia; JPN=Japan; $\mathrm{BRA}=$ Brazil; EU27=European Union 27; SSA=Sub-Saharan Africa.

Source: own calculations.

The projection of female participation rates results from two opposite effects. On the one hand, higher education tends to raise female participation rates; on the other hand, longer studies means less participation of younger women. For advanced economies, the latter effect dominates since participation rates are already high at the beginning of the simulation. This is also the case for China, Brazil and Russia (Figure 2). For some emerging countries, however, there is a significant increase in

\footnotetext{
${ }^{34}$ However no country of the sample experiences a fall in energy productivity in our projections, meaning that they all lie beyond the U-curve turning point at the beginning of the projection. Note that our catch-up process implies that energy productivity observed over the past in advanced economies cannot continue, hence the income elasticity of energy consumption is expected to increase for these countries, while declining in emerging and developing countries, in contrast to past features (see IMF, 2011).
} 
female participation over the projection period. This is especially the case for Sub-Saharan Africa, India and Turkey, where participation rates increase by 5 to 10 percentage points from 2010 to $2050 .^{35}$

\section{Figure 2 - Female participation rates, 1980-2050, selected countries (percent)}

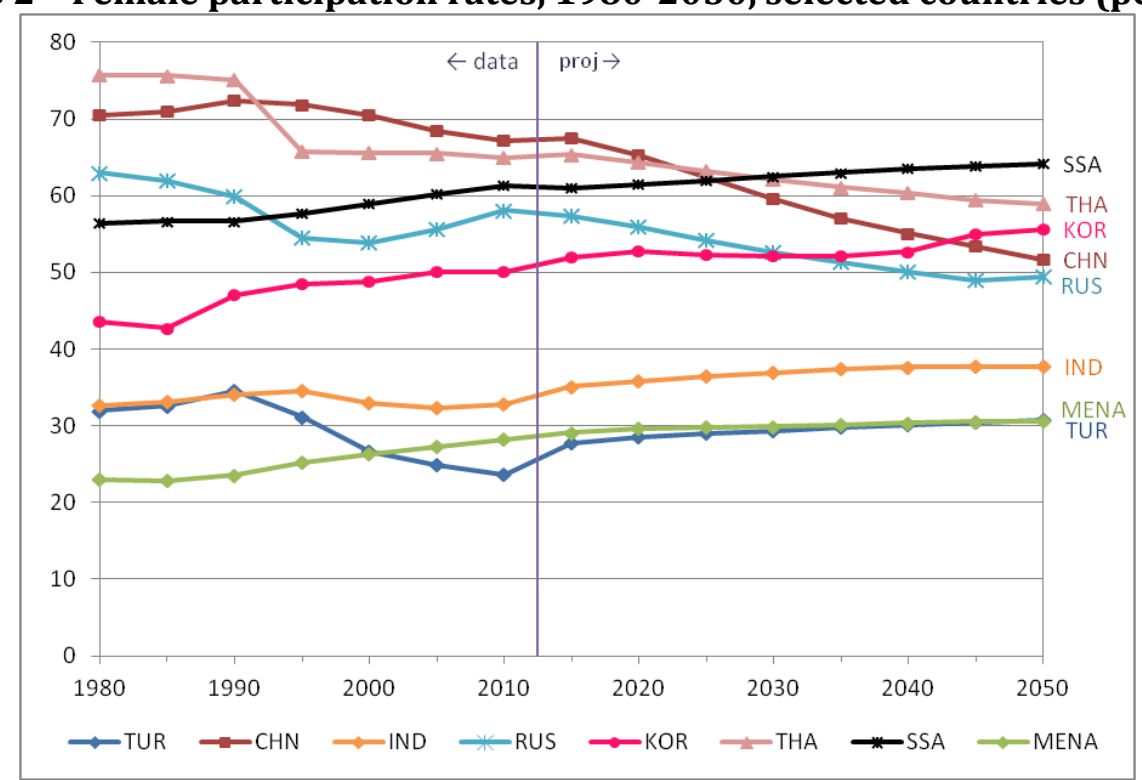

Notations: CHN=People's Republic of China; IND=India; RUS=Russia; BRA=Brazil; TUR=Turkey; IDN=Indonesia; SSA=Sub-Saharan Africa; MENA=Middle-East and North Africa (excl. Turkey).

Source: own calculations.

As reported in Figure 3, our modelling of (imperfect) capital mobility leads to a reversal in the savinginvestment balance in China (that switches to a deficit around 2030), India (that quickly switches to a surplus) and Sub-Saharan Africa (switch to a surplus after 2040). ${ }^{36}$ In contrast, Russia keeps a large surplus along the projection period, whereas Brazil continues running a deficit. These imbalances mean that investment rates can differ by several percentage points from saving rates all along the period, although the sign of the gap changes over time in some countries.

\footnotetext{
${ }^{35}$ In the case of Turkey, there is an initial catch-up to the average behavior of the MENA region in terms of education. 36

The United States moves close to balance at the 2050 horizon
} 


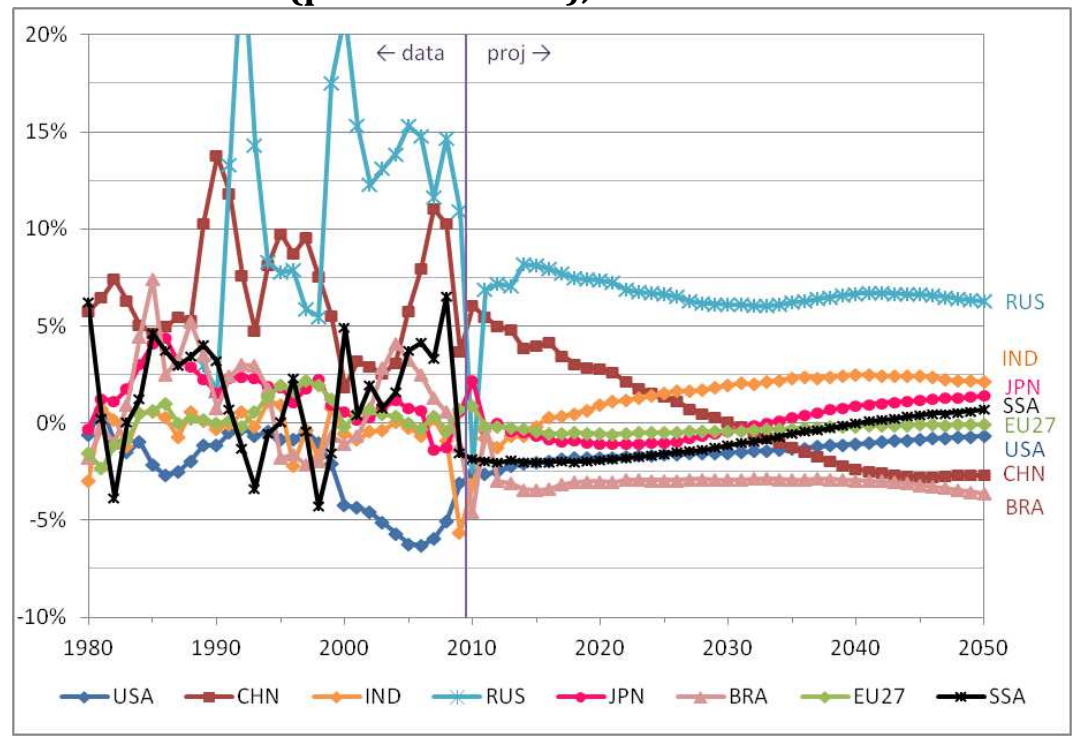

Note: savings minus gross fixed capital formation, see Figure 1 for notations. Source: own calculations.

Lastly, the role of valuation effects must be emphasized. In the Balassa-Samuelson framework described above, TFP and energy productivity catch-up involve a real exchange-rate appreciation against the US dollar, at a speed that depends on the share of non-tradable goods in each economy. As might be expected, India, China and Russia especially enjoy strong real exchange-rate appreciation up to 2050 (Figure 4). Japan also sees its real exchange rate appreciate steadily because its GDP growth heavily relies on TFP growth, in the context of a declining workforce. 
Figure 4 - Bilateral real exchange rate against the United States, 1980-2050*

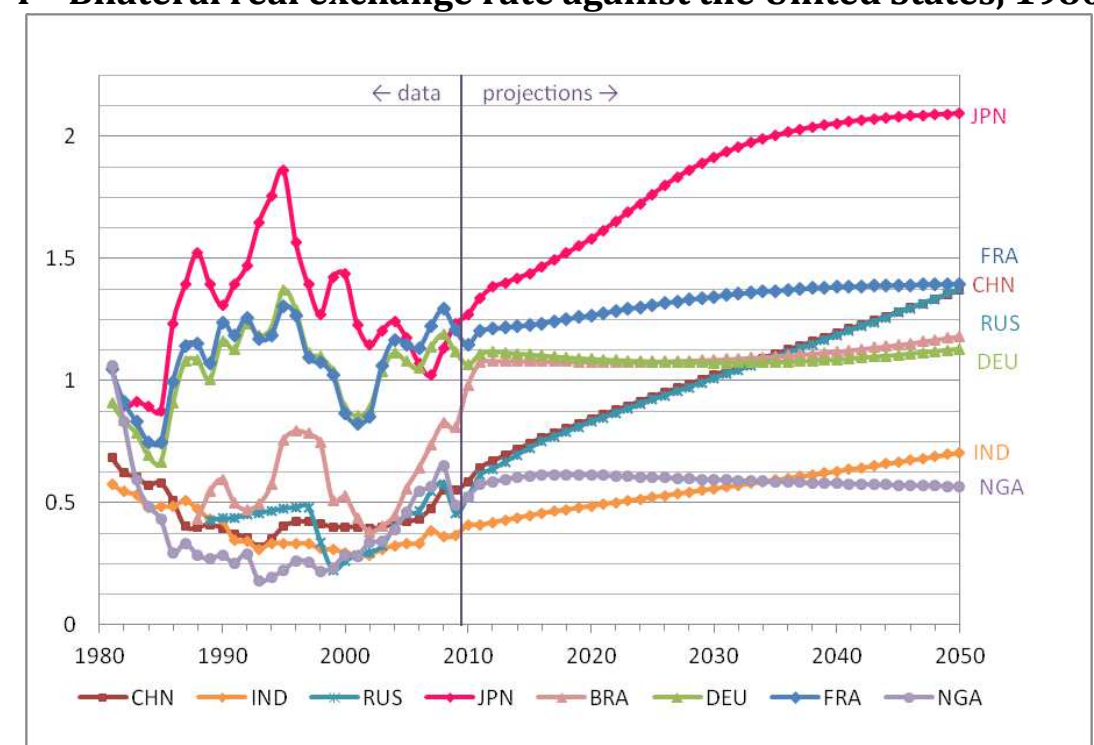

* A rise refers to a real appreciation against the United States.

Notations: see Figure 1; FRA=France; DEU=Germany; NGA=Nigeria.

Source: own calculations.

\subsection{GDP}

To project the volume of GDP for our sample of 147 countries from 2013 to 2050, we combine labour, capital, TFP and energy productivity. Figure 5 depicts GDP growth rates in volumes. Up to 2025, the highest growth rate is achieved by China, but from 2025 to 2050 it is overtaken by India and SubSaharan Africa on average, the latter outperforming the former around year 2040. After 2030 Japan experiences very low growth rates. This reflects its reduced labour force which is not fully compensated for by capital accumulation and TFP growth, as well as its attaining the TFP frontier and therefore not benefiting anymore from catching-up. 


\section{Figure 5 -5-year average GDP growth rate, 1980-2050 (volume)}

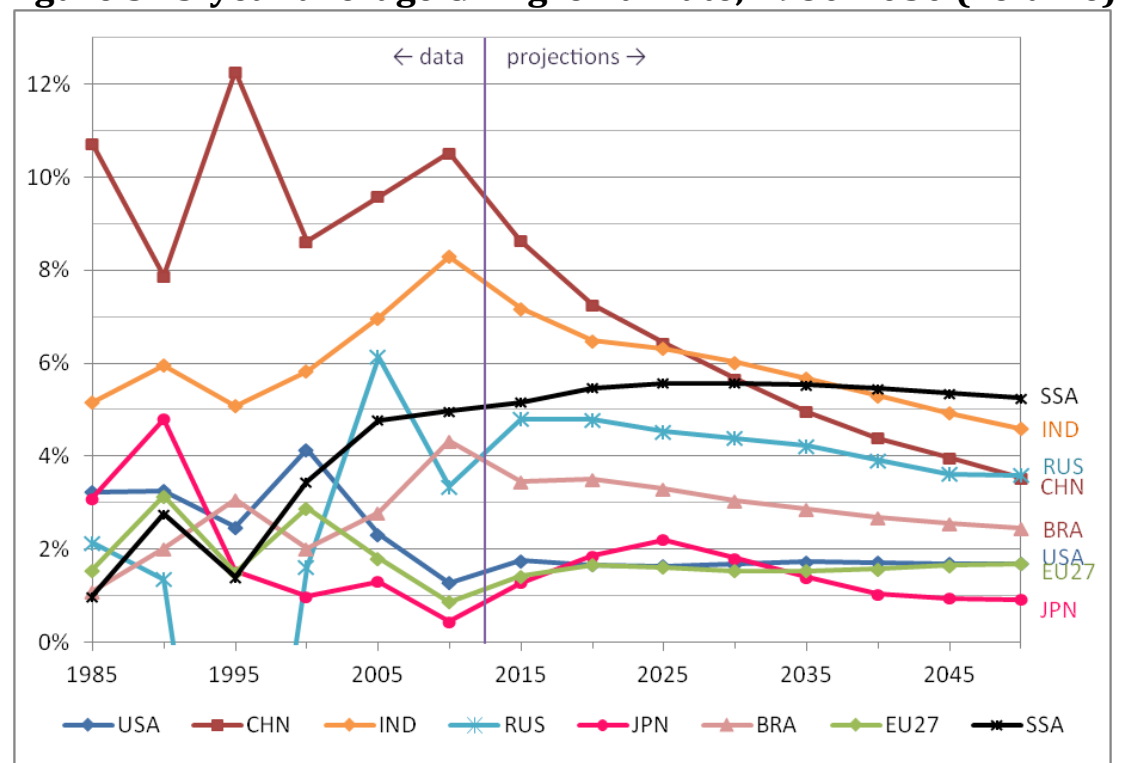

Notations: see Figure 1. Source: own calculations.

Measured in 2005 US dollars, China's GDP could overtake the US one around 2040, and could be 25\% larger than the US in 2050 (Figure 6a). This would make China the largest economy in the world in 2050 (with $21 \%$ of global GDP), followed by the EU27 (if considered as a bloc), the United States and India, the latter overtaking Japan around 2040.

To estimate standards of living, we convert projected GDP into purchasing power parity (PPP) of 2005 and divide this by projected population. Our calculations suggest that China's GDP per capita could reach $92 \%$ of the US level in 2050, despite still low TFP (46\% of US level in 2050). Figure $6 \mathrm{~b}$ further shows that GDP per capita in India and Brazil would reach 33\% and 44\% of the US level in 2050, respectively. Japan would catch up completely with the US at the 2050 horizon, while the EU would remain $18 \%$ below the US level. As for Russia, the combination of a rising oil rent with a declining working force would lead to a steady rise in GDP per capita. 


\section{Figure 6 - Different measures of GDP}

6b. GDP per capita (PPP, \% of

US)

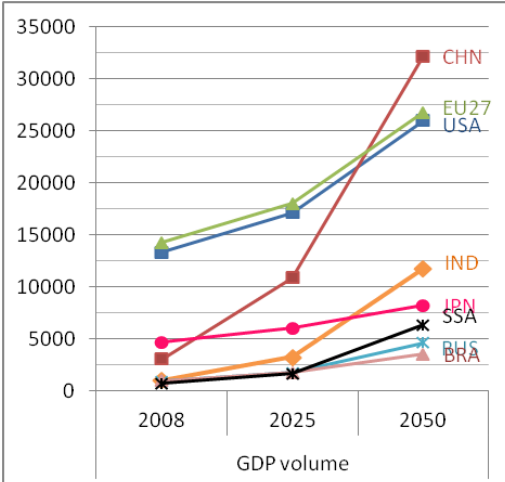

GDPvolume

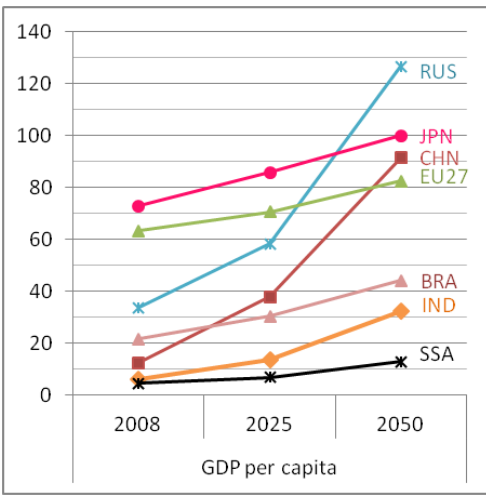

6c. GDP with relative price variations

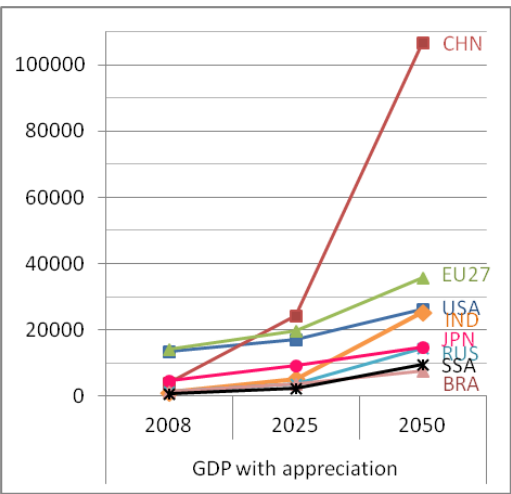

Notations: see Figure 1.

Source: own calculations.

Finally, Figure $6 c$ depicts the evolution of GDPs measured at variable relative prices (this includes both nominal exchange rate and inflation appreciation, without disentangling the two effects). Adding these valuation effects naturally strengthens the shift of the global economy towards China and India, with the latter approaching the size of the US economy at the 2050 horizon (8-9\% of global GDP).

The size of the EU27 now appears significantly larger than that of the US at the same horizon. ${ }^{37}$

\section{SENSITIVITY ANALYSIS}

In this section, we analyse the role of our modelling of energy, female participation and imperfect capital mobility in our projections. ${ }^{38}$ We also study a scenario of institutional convergence.

\subsection{Energy}

Table 5 shows the impact of a higher energy price on GDP in selected countries or areas. Specifically, we retain the higher range of EIA oil price projections (i.e. $65 \%$ more expensive in 2030, which we

\footnotetext{
37 Our projections for Brazil might appear conservative. This is because they are based on econometric relationships estimated for 1980-2009, a period when its average economic performance was relatively poor.

${ }^{38}$ The impact of valuation effects is already clear by comparing GDP projections with and without relative price variations.
} 
extrapolate to reach an increase by $36 \%$ in 2050 compared to the baseline price ${ }^{39}$ ). In a standard GDP projection without energy, switching to a high oil-price scenario would have no impact on GDP. Here, we find that world GDP in volume is reduced by 1.4 percent in 2050 when the oil price is higher by 36 percent. The impact is rather limited in advanced economies where energy productivity is very high at that horizon. ${ }^{40}$ The effect is more marked for less energy-efficient countries. In oil-producing countries, the negative impact of a higher oil price on non-oil GDP is mitigated by higher oil rents.

Table 5 - Impact of energy price in 2050, selected countries

\begin{tabular}{lrrrrr}
\hline & \multicolumn{2}{c}{ Energy intensity in 2050 } & & \multicolumn{2}{c}{ GDP volume in 2050 } \\
\cline { 2 - 3 } \cline { 5 - 6 } & Baseline & $\begin{array}{r}\text { High energy } \\
\text { price }\end{array}$ & $\begin{array}{r}\text { Non-oil GDP } \\
\text { (in \%) }\end{array}$ & $\begin{array}{r}\text { GDP including } \\
\text { oil rents (in \%) }\end{array}$ \\
\hline USA & 0.9 & 0.8 & -0.8 & -0.7 \\
Japan & 0.6 & 0.6 & -0.5 & -0.5 \\
EU27 & 0.7 & 0.7 & -0.8 & -0.7 \\
Brazil & 1.2 & 1.1 & -2.3 & -1.6 \\
Russia & 2.5 & 2.4 & -7.0 & -4.3 \\
India & 2.0 & 2.0 & -3.4 & -3.9 \\
China & 1.9 & 1.8 & -3.4 & -3.3 \\
Turkey & 0.9 & 0.9 & -1.8 & -1.8 \\
MENA & 1.6 & 1.4 & -6.8 & -1.0 \\
SSA & 2.8 & 2.6 & -14.2 & -13.0 \\
\hline World & 1.4 & 1.3 & -2.9 & -2.4 \\
\hline Not
\end{tabular}

Note: MENA=Middle-East and North-Africa; SSA=Sub-Saharan Africa. Percentage changes compared to the baseline presented in Section 3. Interpretation: world GDP in volume is reduced by 2.4 percent in 2050 when the oil price is $36 \%$ higher than in the baseline (last column, last row).

Source: own calculations.

\subsection{Female participation}

We now measure the impact of our modeling of female participation rates at the 2050 horizon by comparing it with a more standard one where female participation rates are modeled like for males, i.e. their variations are largely bounded. The results are reported in Table 6. Our modeling leads to

\footnotetext{
${ }^{39}$ The corresponding real prices in constant 2005 USD are respectively 185 USD in 2030, compared to 112 USD in the baseline; and 207 USD in 2050 compared to 152 USD in our reference case. We are unable to project extreme oilprice scenarios where the relative price of energy would exceed energy productivity (in that case GDP would be undefined, see Equation (1.2) in Section 1.1).

${ }^{40}$ This benign result for advanced economies is in line with IMF (2011).
} 
generally higher participation rates, with an impact on the labor force at the 2050 horizon that reaches $+15.1 \%$ in Turkey, $+7.9 \%$ in Japan, $+7 \%$ in India and $+5.4 \%$ in the MENA region. Conversely, the net impact of education catch-up of our modeling of the labor force is slightly negative for Sub-Saharan Africa. On the whole, there is a positive (although limited) impact on global GDP $(+1.6 \%)$.

Table 6 - Impact of female participation rates in 2050, selected countries

\begin{tabular}{|c|c|c|c|c|}
\hline & \multicolumn{2}{|c|}{ Female participation rates $(\%)$} & \multirow{2}{*}{$\begin{array}{c}\text { Labor force } \\
\text { Variation in } 2050 \\
\text { Baseline/ILO }(\%)\end{array}$} & \multirow{2}{*}{$\begin{array}{c}\text { GDP in volume } \\
\text { Variation in } 2050 \\
\text { Baseline/ILO (\%) }\end{array}$} \\
\hline & Baseline & "ILO"* & & \\
\hline USA & 55.1 & 54.0 & +0.9 & +0.6 \\
\hline Japan & 51.8 & 43.4 & +7.9 & +8.3 \\
\hline EU27 & 43.0 & 44.6 & -1.7 & -1.1 \\
\hline Brazil & 50.6 & 57.2 & -5.5 & -4.1 \\
\hline Russia & 49.4 & 50.9 & -1.5 & -1.0 \\
\hline India & 37.8 & 29.6 & +7.0 & +6.7 \\
\hline China & 51.7 & 50.1 & +1.4 & +1.6 \\
\hline Turkey & 30.8 & 17.9 & +15.1 & +14.2 \\
\hline MENA & 30.0 & 24.8 & +5.4 & +3.5 \\
\hline SSA & 64.5 & 65.9 & -1.0 & -0.4 \\
\hline World & 48.5 & 46.5 & +1.6 & +1.6 \\
\hline
\end{tabular}

* Same methodology for females as for males.

Note: MENA=Middle-East and North-Africa (excl. Turkey); SSA=Sub-Saharan Africa.

Interpretation: world GDP in volume is increased by 1.6 percent in 2050 when the impact of education on female participation is accounted for (last column, last row).

Source: own calculations.

\subsection{Imperfect capital mobility}

Our next exercise is to compare our projections including imperfect capital mobility with a closedeconomy projection where investment always equals savings on a country-by-country basis. The results are depicted in Table 7. By construction, countries that are in current-account surplus over 2010-2050 get a lower investment rate in the baseline, hence lower capital accumulation in an open economy versus a closed economy. GDP is then lower too. ${ }^{41}$ This is the case of Russia, the MENA region and, to a lesser extent, of India or Japan. China moves from this category to the deficit one around 2030. On the whole, it gets a slightly higher investment rate on average, hence a higher GDP in

\footnotetext{
${ }^{41}$ Unlike GDP, GNP may turn higher in an open economy for these countries.
} 
2050 under the open-economy scenario, compared to the closed one. The United States and Brazil also benefit from capital openness. On the whole, the last line of Table 7 shows that (imperfect) capital mobility leads to a higher world GDP by $0.02 \%$ at the 2050 horizon, which is consistent with the standard neoclassical result of a better allocation of capital worldwide, though with a limited magnitude. Note that our model by construction depicts a peaceful financial globalization with no financial crises.

Table 7 - Impact of imperfect capital mobility in 2050, selected countries Investment rate $\frac{(2010-50 \text { average, in \%) }}{\text { Closed }} \quad \frac{\text { GDP in volume }}{\text { variation in } 2050}$

\begin{tabular}{lrrr} 
& Baseline & economy & (Baseline/closed \%) \\
\hline USA & 14.8 & 13.6 & +3.0 \\
Japan & 20.7 & 21.0 & -1.2 \\
EU27 & 16.8 & 17.0 & +0.3 \\
Brazil & 17.1 & 14.0 & +7.9 \\
Russia & 20.7 & 27.8 & -12.3 \\
India & 20.1 & 22.3 & -4.8 \\
China & 30.9 & 29.9 & +1.9 \\
MENA & 20.6 & 24.9 & -1.1 \\
SSA & 16.1 & 16.9 & -0.1 \\
\hline World & 20.1 & 20.5 & +0.02 \\
\hline
\end{tabular}

Note: MENA=Middle-East and North-Africa; SSA=Sub-Saharan Africa. Interpretation: world GDP in volume is increased by 0.02 percent in 2050 when international capital mobility is introduced (last column, last row).

Source: own calculations.

\subsection{Institutional convergence}

Our projection exercise relies on econometric estimations which in most cases include country (our country group) fixed effects. These fixed effects are supposed to capture unobserved and time invariant country characteristics. However, over such a long period, one cannot exclude changes in these factors which encompass different aspects of institutions. In this last sensitivity exercise, we measure how a convergence of some institutional features could affect our projections. Since our projections are based on a reference period (rather than 
fixed effects), our scenario relies on a convergence of variables average (measured over the reference period). Regarding education, energy productivity and the Feldstein-Horioka relationship, institutions are also embodies in slope estimates differences between the different country groups. The targets towards which institutions (as captured by reference averages and estimated slopes) are supposed to converge linearly are listed in Table 8. It must be noted that the selection of one or several reference country(ies) for convergence is highly debatable for at least two reasons: (i) it is not always easy to see which countries have the "good" institutions, and (ii) there is no reason for all behaviors converging at the same pace.

The simulation is however instructive as a sensitivity exercise.

Table 8: reference country(ies) for institutional convergence

\begin{tabular}{|c|c|}
\hline Variable & Reference country(ies) \\
\hline Savings rate & Average OECD \\
\hline Education & $\begin{array}{l}\text { Highest coefficient (Easter Europe, Western Europe } \\
\text { or North America, depending on the age group and } \\
\text { education level) }\end{array}$ \\
\hline $\begin{array}{l}\text { Female } \\
\text { participation }\end{array}$ & Average OECD \\
\hline TFP growth & $\begin{array}{l}\text { Average of highest significant fixed effects: EU27, } \\
\text { Brunei, China, Hong Kong, Korea, Macao, } \\
\text { Singapore, China, Australia, Croatia, Iceland, New } \\
\text { Zealand, Norway, Slovenia and Switzerland. }\end{array}$ \\
\hline $\begin{array}{l}\text { Energy } \\
\text { productivity }\end{array}$ & $\begin{array}{l}\text { Average of significantly positive fixed effects: } \\
\text { Austria, Ireland, Italy and Norway. }\end{array}$ \\
\hline $\begin{array}{l}\text { Feldstein- } \\
\text { Horioka }\end{array}$ & Average OECD \\
\hline
\end{tabular}

The results are reported in Table 9. This convergence scenario clearly raises the overall level of education and productivity (both energy productivity and TFP). In contrast, the impact of institutional convergence on female participation and capital accumulation varies across countries, with a strong, positive effect in India and MENA countries, whereas female participation falls in China and Sub-Saharan Africa. As for capital accumulation, it is reduced 
at the global level due to reduced saving rates in emerging countries. The net effect of all these changes is an increase by 0.3 percentage point of global GDP growth on average over the 2012-50 period, benefiting mostly emerging countries, especially India which cumulates additional investment in education, increased female participation and faster productivity growth. Growth rates are slightly reduced in advanced economies.

Table 9: impact of institutional convergence (pp change in 2050 or over 2012-50)

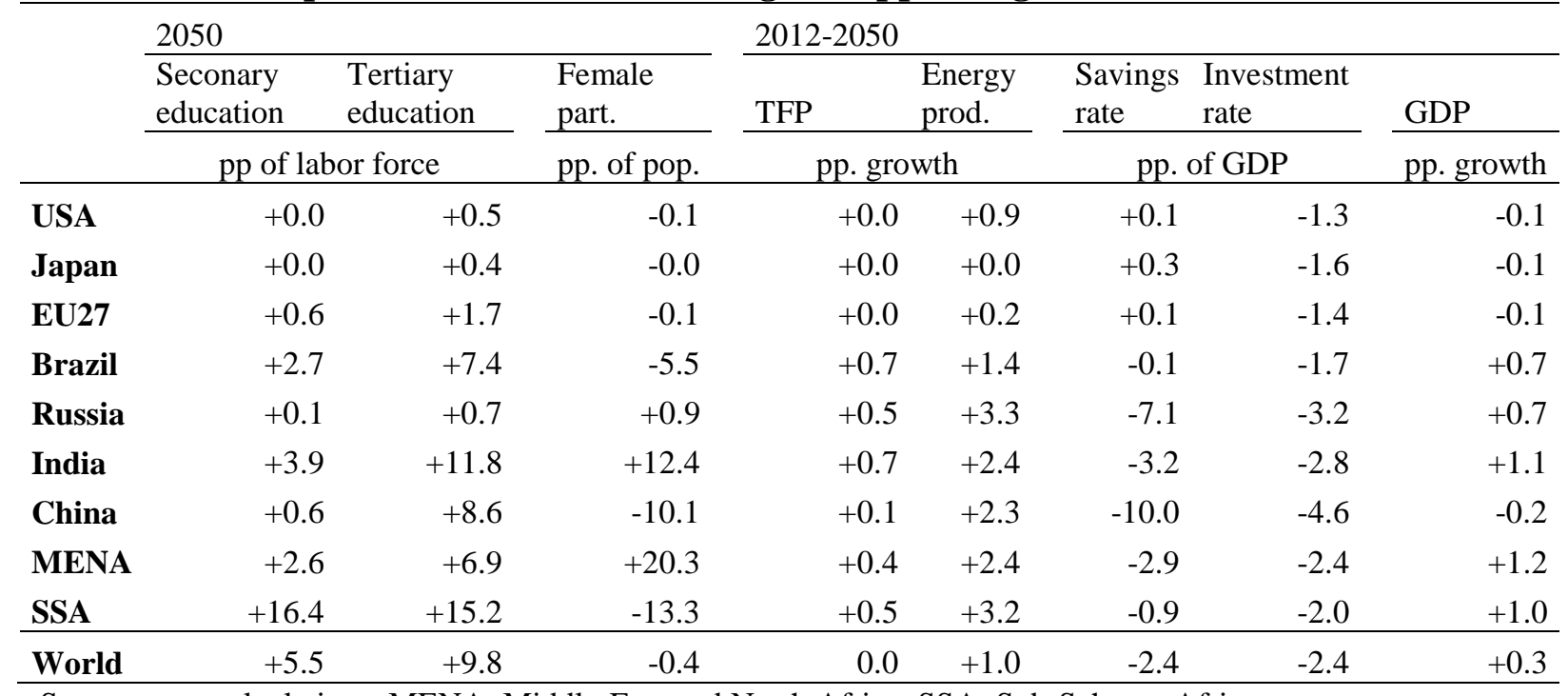

Source: own calculations. MENA: Middle-East and North Africa; SSA: Sub-Saharan Africa.

\section{CONCLUSION}

A theoretically consistent model of world economic growth is especially important for projecting GDP in several countries over a long time period. To this purpose we have developed MaGE (Macroeconometrics of the Global Economy), a theoretically founded framework to project long-term growth in a consistent way for the world economy. The model improves on the literature by incorporating in a consistent way endogenous energy productivity, female participation rates and valuation effects, and in assuming imperfect international capital mobility. We rely on a nested CES production function and on original econometric estimations to produce a set of macroeconomic projections for 147 countries at the 2050 horizon. These distinctive features significantly affect GDP levels for specific countries, without significant impact on the global economy. 
Although our results, as any study of this type, should be treated with caution, we believe that they provide useful benchmarks for downstream studies on world commodity demand, international trade, financing capacities, global power, etc. They also provide a fully-transparent, theoretically-grounded and flexible tool for the research community.

\section{REFERENCES}

Aghion, P. \& Howitt, P. (1992), 'A Model of Growth Through Creative Destruction', Econometrica 60(2), 323-351.

Bahmani-Oskooee, M. \& Chakrabarti, A. (2005), 'Openness, size, and the saving-investment relationship', Economic Systems 29(3), 283-293.

Barro, R. J. \& Lee, J.-W. (2010), 'A new data set of educational attainment in the world, 1950-2010', NBER Working Paper (15902).

Benhabib, J. \& Spiegel, M. (1994), 'The role of human capital in economic development evidence from aggregate cross-country data', Journal of Monetary economics 34(2), 143-173.

Blanchard, O. \& Giavazzi, F. (2002), 'Current Account Deficits in the Euro Area: The End of the Feldstein-Horioka Puzzle?', Brookings Papers on Economic Activity 2002(2), 147-186.

Bloom, D., Canning, D., Fink, G. \& J. Finlay (2009), 'Fertility, female labor force participation, and the demographic dividend', Journal of Economic Growth 14(2), 79-101.

Chakrabarti, A. (2006), 'The saving-investment relationship revisited: New evidence from multivariate heterogeneous panel cointegration analyses', Journal of Comparative Economics 34(2), 402-419.

Chateau, J., Dellink, R., Lanzi, E. \& B. Magne (2012), 'Long-term economic growth and environmental pressure: reference scenarios for future global projections', mimeo OECD.

Coiteux, M. \& Olivier, S. (2000), 'The saving retention coefficient in the long run and in the short run: evidence from panel data', Journal of International Money and Finance 19(4), 535-548.

David, P. \& Van de Klundert, T. (1965), 'Biased efficiency growth and capital-labor substitution in the US, 1899-1960', The American Economic Review, 357-394.

Deaton, A., \& A. Heston (2010), 'Understanding PPPs and PPP-based national accounts', American Economic Journals: Macroeconomics, 2(4): 1-35.

De Gregorio, J., Giovannini, A. \& H.C. Wolf (1994), 'International evidence on tradable and 30 
nontradable inflation', European Economic Review 38(6), 1225-1244.

Duval, R. \& de la Maisonneuve, C. (2010), 'Long-run growth scenarios for the world economy', Journal of Policy Modeling 32(1), 64-80.

Feenstra, R., Ma, H., Neary, J. \& D. Rao (2012), 'Who Shrunk China? Puzzles in the Measurement of Real GDP', NBER Working Paper 17729.

Feldstein, M. \& Horioka, C. (1980), 'Domestic Saving and International Capital Flows', The Economic Journal 90(358), 314-329.

Griliches, Z. \& Mairesse, J. (1995), "Production Functions: The Search for Identification," NBER Working Papers 5067.

Herwartz, H. \& Xu, F. (2010), 'A functional coefficient model view of the Feldstein-Horioka puzzle', Journal of International Money and Finance 29(1), 37-54.

Higgins, M. (1998), 'Demography, National Savings, and International Capital Flows', International Economic Review 39(2), 343-369.

International Monetary Fund (2011), 'Oil scarcity, growth and global imbalances', World Economic Outlook, Chapter 3, April.

Johansson, A., Guillemette, Y., Martin, F., Turner, D., Nicoletti, G., de la Maisonneuve, C., Bagnoli, P., Bousquet, G., \& F. Spinelli (2013), 'Long-term growth scenarios', OECD Economics Department working paper 1000 .

Johnson, S., Larson, W., Papageorgiou, C. \& A. Subramanian (2009), 'In newer better? Penn World Table revisions and their impact on growth estimates', Center for Global Development working paper 191, November.

Mamingi, N. (1997), 'Saving-investment correlations and capital mobility: The experience of developing countries', Journal of Policy Modeling 19(6), 605-626.

Mankiw, N. G.; Romer, D. \& Weil, D. N. (1992), 'A Contribution to the Empirics of Economic Growth', The Quarterly Journal of Economics 107(2), 407-437.

Markandya, A. \& Pedroso-Galinato, S. (2007), 'How substitutable is natural capital?', Environmental and Resource Economics 37, 297-312.

Masson, P. R.; Bayoumi, T. A. \& Samiei, H. (1998), 'International Evidence on the Determinants of Private Saving', World Bank Economic Review 12(3), 483-501. 
Metcalf, G. (2008), 'An Empirical Analysis of Energy Intensity and Its Determinants at the State Level', The Energy Journal 29(3), 1-26.

OECD (2012), 'Medium and long-term scenarios for global growth and imbalances', OECD Economic Outlook 2012/1, Chapter 4, 191-224.

Pedroni, P. (1999), 'Critical values for cointegration tests in heterogeneous panels with multiple regressors', Oxford Bulletin of Economics and Statistics, S1, 61, 653-670.

Pedroni, P. (2004), 'Panel Cointegration: Asymptotic and finite sample properties of pooled time series tests with an application to the PPP hypothesis', Econometric Theory 20(03), 597-625.

Pelgrin, F., and S. Schich (2004), 'National saving-investment dynamics and international capital mobility', Bank of Canada Working Paper 2004-14.

Poncet, S. (2006), 'The Long Term Growth Prospects of the World Economy: Horizon 2050', CEPII Working Paper 2006-16.

Ponomareva, N. \& H. Katayama (2010), 'Does the version of the Penn World Tables matter? An analysis of the relationship between growth and volatility', Canadian Journal of Economics 43(1), 152 179.

Rogoff, K. (1996), 'The Purchasing Power Parity Puzzle', Journal of Economic Literature 34(2), 647668.

van Ark, B., Buyst, E., van Zanden, J. \& C. Núcez (1998), Historical benchmark comparisons of output and productivity, Vol. 10, Universidad de Sevilla.

van der Werf, E. (2008), 'Production functions for climate policy modeling: An empirical analysis', Energy Economics 30(6), 2964-2979.

Vandenbussche, J.; Aghion, P. \& Meghir, C. (2006), 'Growth, distance to frontier and composition of human capital', Journal of economic growth 11(2), 97-127.

Westerlund, J. (2007), 'Testing for Error Correction in Panel Data', Oxford Bulletin of Economics and Statistics 69(6), 709-748. 
APPENDIX A: DATA SOURCES

\begin{tabular}{|c|c|c|c|}
\hline Variable & Detail & Period & Sources \\
\hline GDP & Constant USD of 2005 & $1980-2012$ & $\begin{array}{l}\text { World Bank, International } \\
\text { Monetary Fund, van Ark et al. } \\
\text { (1998), Cepii-Chelem. }\end{array}$ \\
\hline Oil rent & $\%$ of GDP & $1980-2009$ & World Bank \\
\hline Population & Million, five-year age groups & $1980-2050$ & $\begin{array}{l}\text { United Nations, median fertility } \\
\text { scenario }\end{array}$ \\
\hline $\begin{array}{l}\text { Participation } \\
\text { rate }\end{array}$ & $\%$ per age group and gender & $\begin{array}{l}\text { 1980-2020, } \\
\text { 5-year step }\end{array}$ & $\begin{array}{ll}\text { International } & \text { labour } \\
\text { organization } & \end{array}$ \\
\hline Education & $\begin{array}{l}\text { Share of age group with a } \\
\text { primary, secondary or tertiary } \\
\text { diploma }\end{array}$ & $\begin{array}{l}\text { 1980-2010, } \\
\text { 5-year step }\end{array}$ & $\begin{array}{l}\text { Barro and Lee (2010, revision } \\
1.2)\end{array}$ \\
\hline $\begin{array}{l}\text { Energy } \\
\text { consumption }\end{array}$ & $\begin{array}{l}\text { Primary energy use before } \\
\text { transformation }\end{array}$ & $1980-2008$ & World Bank \\
\hline Oil price & $\begin{array}{l}\text { Constant USD of } 2008 \text {, which are } \\
\text { then converted into constant USD } \\
\text { of } 2005 \text { by dividing by } 1.102\end{array}$ & $1980-2035$ & $\begin{array}{l}\text { US Energy Information Agency, } \\
\text { medium projection }\end{array}$ \\
\hline $\begin{array}{l}\text { Energy } \\
\text { productivity }\end{array}$ & $\begin{array}{l}\text { Derived from optimal behaviour } \\
\text { (Equation 1.2) }\end{array}$ & $1980-2008$ & Own calculations \\
\hline $\begin{array}{l}\text { Total factor } \\
\text { productivity }\end{array}$ & $\begin{array}{l}\text { Derived from production function } \\
\text { (equation 1.3) }\end{array}$ & $1980-2008$ & Own calculations \\
\hline Saving rate & Private and public & $1980-2008$ & World Bank \\
\hline Investment rate & $\begin{array}{l}\text { Gross and gross fixed capital } \\
\text { formation, private and public }\end{array}$ & $1980-2008$ & World Bank \\
\hline Capital stock & $\begin{array}{l}\text { Permanent inventory with } 6 \% \\
\text { depreciation }\end{array}$ & 1960-2009 & $\begin{array}{l}\text { Penn World Tables }(1960) \text { and } \\
\text { own calculations }(1961-2009 \\
\text { or } 1960-2009 \text {, depending on } \\
\text { data availability) }\end{array}$ \\
\hline $\begin{array}{l}\text { Real exchange } \\
\text { rate }\end{array}$ & $\begin{array}{l}\text { Nominal exchange rate against } \\
\text { USD divided by PPP conversion } \\
\text { factor }\end{array}$ & 1980-2009 & $\begin{array}{l}\text { World } \underset{42}{\text { Bank }} \text { and } \text { own } \\
\text { calculations }\end{array}$ \\
\hline $\begin{array}{l}\text { Share of traded } \\
\text { goods in } \\
\text { production/ in } \\
\text { consumption }\end{array}$ & $\begin{array}{l}\text { Calibrated for year } 2004 \text { based on } \\
\text { the GTAP database ( } 57 \text { sectors, } \\
\text { including services) }\end{array}$ & 2004 & $\begin{array}{l}\text { Global Trade Analysis Project } \\
\text { (GTAP) and own calculations. }\end{array}$ \\
\hline
\end{tabular}

${ }^{42}$ Based on the International Comparison Project (ICP), this dataset has received a number of criticisms, notably following the large downward revision of Chinese PPP GDP in 2008. In fact, key methodological choices such as the coverage of price surveys (either urban or also rural), the weighting schemes of price indices, or the calibration of productivity in services or the valuation of imports and exports, may heavily impact on the results (see Deaton and Heston, 2010, Feenstra et al., 2012). We nevertheless rely on this database which is readily available for a large number of countries over our estimation period. Given the uncertainty surrounding the data, our results in terms of evolutions may be more meaningful than those in terms of absolute values.

${ }^{43}$ See www.gtap.agecon.purdue.edu 


\section{APPENDIX B: ECONOMETRIC ESTIMATIONS}

\section{a. Female participation rates}

Table B. 1 - Female participation rates estimation by age group, five-year intervals

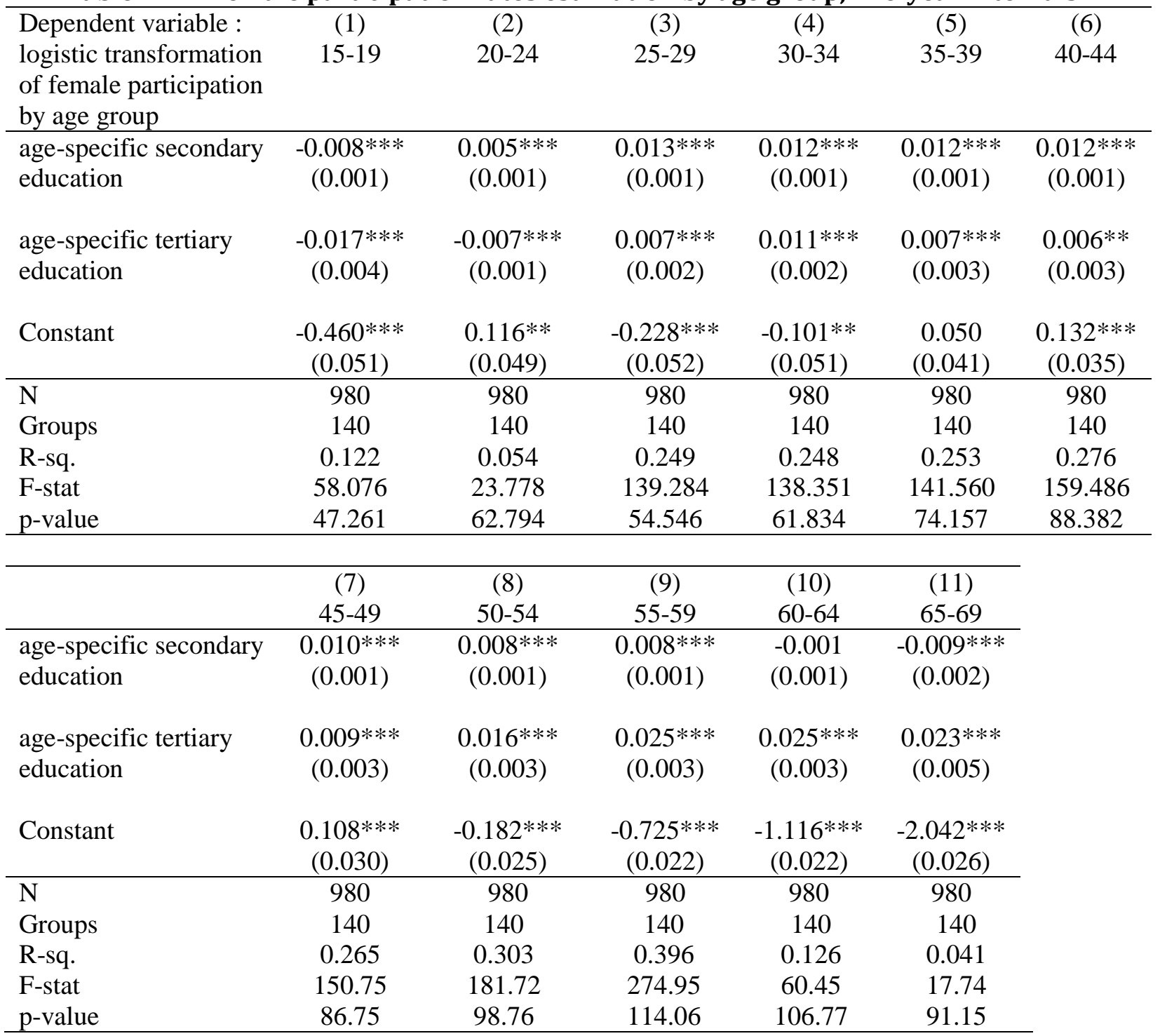

Standard errors in parentheses. $* \mathrm{p}<0.1, * * \mathrm{p}<0.05, * * * \mathrm{p}<0.01$.

Source: own calculations. 


\section{b. Education}

We rely on a catch-up model of school attainment for two successive age groups: 15-19, and 20-24 years, and three education levels - primary, secondary and tertiary. ${ }^{44}$ The leader country is defined as the country displaying the highest share of educated people for each age group and each level of education. It may vary over time. ${ }^{45}$ We first estimate the following, catching-up process, on five-yearinterval data:

$\ln \left(\frac{h_{a, i, t}^{l}}{h_{a, i, t-1}^{l}}\right)=\lambda_{r}^{l} \ln \left(\frac{h_{a, t-1}^{l *}}{h_{a, t-1}^{l}}\right)+\epsilon_{i, t}$

where $h_{a, i, t}^{l}$ is the proportion of the age-group $a$ in country $i$ having a level of education of at least $l$ $(l=1,2,3)$ in year $t, h_{a, t}^{l *}$ is the corresponding level of schooling in the leader country, $h_{a, i, t-1}^{l}$ and $h_{a, i, t-1}^{l *}$ are the corresponding variables five year before, and $\lambda_{r}^{l}>0$ is the catch-up coefficient that is assumed to vary across regions $r$. We perform a weighted estimation of Equation (B.1) (using the population shares within each region as a weighing device, and clustering the residuals).

The results are reported in Table B.2. There is evidence of a significant catch-up for all regions and all education levels. The speed varies across regions, with former USSR and Eastern Europe being the fastest and Indian region and Sub-Saharan Africa being the slowest. We can also note that tertiary catch-up speeds are lower than for primary and secondary education.

For primary and secondary education, we will assume the leader level to remain fixed at $100 \%$ of both age groups, consistent with the attainment in 2010. As for tertiary education, we fit a logistic

\footnotetext{
${ }^{44}$ Barro and Lee (2010) follow the UNESCO "ISCED" classification that defines the first tertiary level diploma (level 5) as "comprising education which begins at the age of 17 or 18, lasts about four year, and leads to an award not equivalent to a first university degree." Hence we can safely assume that this first level of tertiary education (which is a minimum requirement for our tertiary-education category) is completed before 24 years old, so we can concentrate on the 15-19 and 20-24 age groups.

${ }^{45}$ Several countries can appear the leader level at least for one age group during a sub-period. The main primary education leaders are Austria, Japan, France and Switzerland. The main secondary education leaders are the United States, Australia, Norway and New Zealand. The main tertiary education leaders are the United States, Australia, New Zealand and the Russian Federation.
} 
functional form such that tertiary education for age-group 5 (20-24 years) increases over time without ever exceeding $100 \%$ :

$\ln \left(\frac{h_{5, t}^{3}{ }^{*}}{1-h_{5, t}^{3}}\right)=\zeta_{0}+\zeta_{1} t+\epsilon_{t}$

All coefficients are significant at a $1 \%$ confidence level, with an R-squared of 0.917 . As expected, tertiary education rises steadily over time in the leader country for the 20-24 age group, with $\xi_{0}=-91.5$ and $\xi_{1}=0.046$

For all countries, the proportion of primary, secondary and tertiary education attainment in each of our 11 age groups (from 15-19 to 64-69) is then obtained based on the size and ageing process of the 1519 and 20-24 groups. ${ }^{46}$ The share of different levels of education in the working-age population is ultimately recovered based on the age structure of the population.

\footnotetext{
${ }^{46}$ For the leader country, tertiary education of the 15-19 age group is recovered from that of the 20-24 group, based on the observed correlation of 97 percent between the two: a one percent increase in tertiary education for the 20-24 group occurs together with a 0.41 percent increase in that of the 15-19 group.
} 
Table B. 2 - Education catch-up process, by education level, age group and region

\begin{tabular}{|c|c|c|c|c|c|c|}
\hline \multirow{3}{*}{$\begin{array}{l}\text { Dependent } \\
\text { variable: } \\
\text { education growth } \\
\text { by age group }\end{array}$} & \multicolumn{2}{|c|}{ Primary } & \multicolumn{2}{|c|}{ Secondary } & \multicolumn{2}{|c|}{ Tertiary } \\
\hline & (1) & (2) & (3) & (4) & (5) & (6) \\
\hline & Age 4 & Age 5 & Age 4 & Age 5 & Age 4 & Age 5 \\
\hline Western Europe & $\begin{array}{c}0.130^{* * *} \\
(0.039)\end{array}$ & $\begin{array}{c}0.273^{* * * *} \\
(0.083)\end{array}$ & $\begin{array}{l}0.220^{* * *} \\
(0.056)\end{array}$ & $\begin{array}{l}0.200^{* * *} \\
(0.013)\end{array}$ & $\begin{array}{c}0.402 * * \\
(0.157)\end{array}$ & $\begin{array}{c}0.217 * * * \\
(0.028)\end{array}$ \\
\hline $\begin{array}{l}\text { Eastern Europe } \\
\text { and former USSR }\end{array}$ & $\begin{array}{c}0.250 * * * \\
(0.030)\end{array}$ & $\begin{array}{c}0.326^{* * *} \\
(0.071)\end{array}$ & $\begin{array}{c}0.143 * * * \\
(0.053)\end{array}$ & $\begin{array}{c}0.273 * * * \\
(0.034)\end{array}$ & $\begin{array}{c}0.324 * * * \\
(0.026)\end{array}$ & $\begin{array}{c}0.235^{* * * *} \\
(0.017)\end{array}$ \\
\hline $\begin{array}{l}\text { North America, } \\
\text { Oceania and Japan }\end{array}$ & $\begin{array}{c}0.205^{* * *} \\
(0.064)\end{array}$ & $\begin{array}{c}0.173^{* * * *} \\
(0.025)\end{array}$ & $\begin{array}{l}0.456^{* * *} \\
(0.075)\end{array}$ & $\begin{array}{l}0.275 * * * \\
(0.015)\end{array}$ & $\begin{array}{c}0.188 * * * \\
(0.062)\end{array}$ & $\begin{array}{c}0.289 * * * \\
(0.030)\end{array}$ \\
\hline Latin America & $\begin{array}{c}0.192 * * * \\
(0.007)\end{array}$ & $\begin{array}{c}0.204 * * * \\
(0.019)\end{array}$ & $\begin{array}{c}0.136^{* * *} \\
(0.015)\end{array}$ & $\begin{array}{c}0.148 * * * \\
(0.008)\end{array}$ & $\begin{array}{c}0.181 * * * \\
(0.017)\end{array}$ & $\begin{array}{c}0.133 * * * \\
(0.009)\end{array}$ \\
\hline $\begin{array}{l}\text { Mediterranean } \\
\text { region }\end{array}$ & $\begin{array}{c}0.178^{* * * *} \\
(0.014)\end{array}$ & $\begin{array}{c}0.177 * * * \\
(0.009)\end{array}$ & $\begin{array}{c}0.188 * * * \\
(0.016)\end{array}$ & $\begin{array}{c}0.156^{* * *} \\
(0.009)\end{array}$ & $\begin{array}{c}0.211^{* * * *} \\
(0.034)\end{array}$ & $\begin{array}{c}0.132 * * * \\
(0.009)\end{array}$ \\
\hline Chinese region & $\begin{array}{c}0.148^{* * *} \\
(0.019)\end{array}$ & $\begin{array}{c}0.265^{* * *} \\
(0.029)\end{array}$ & $\begin{array}{c}0.140 * * * \\
(0.012)\end{array}$ & $\begin{array}{c}0.196^{* * *} \\
(0.017)\end{array}$ & $\begin{array}{c}0.191 * * * \\
(0.019)\end{array}$ & $\begin{array}{c}0.0852 * * * \\
(0.005)\end{array}$ \\
\hline $\begin{array}{l}\text { Sub-Saharan } \\
\text { Africa }\end{array}$ & $\begin{array}{c}0.125 * * * \\
(0.016)\end{array}$ & $\begin{array}{c}0.111^{* * *} \\
(0.011)\end{array}$ & $\begin{array}{c}0.0763 * * * \\
(0.008)\end{array}$ & $\begin{array}{c}0.0950 * * * \\
(0.008)\end{array}$ & $\begin{array}{l}0.0430 \\
(0.026)\end{array}$ & $\begin{array}{c}0.0601 * * * \\
(0.005)\end{array}$ \\
\hline India region & $\begin{array}{c}0.120 * * * \\
(0.007)\end{array}$ & $\begin{array}{c}0.114 * * * \\
(0.010)\end{array}$ & $\begin{array}{c}0.154 * * * \\
(0.030)\end{array}$ & $\begin{array}{c}0.136^{* * * *} \\
(0.005)\end{array}$ & $\begin{array}{c}0.102 * * * \\
(0.005)\end{array}$ & $\begin{array}{l}0.0892 * * * \\
(0.005)\end{array}$ \\
\hline R-sq & 0.529 & 0.488 & 0.323 & 0.485 & 0.273 & 0.186 \\
\hline $\mathrm{N}$ & 1669 & 1663 & 1626 & 1662 & 1054 & 1630 \\
\hline Clusters & 140 & 140 & 140 & 140 & 138 & 140 \\
\hline
\end{tabular}

Standard errors in parentheses. ${ }^{*} \mathrm{p}<0.1, * * \mathrm{p}<0.05, * * * \mathrm{p}<0.01$.

Note : 5 -year intervals

Source : own calculations.

\section{c. TFP}

Following Vandenbussche et al. (2006), TFP growth is modeled as the combination of a pure catch-up effect, a pure education effect, and an interaction term between education and catch up. The latter effect refers to the impact of tertiary education on the ability of a country to move the technological frontier itself (see Aghion and Howitt, 1992). Here, we slightly depart from the two cited papers by introducing both secondary and tertiary education in the equation. As noted for instance by Benhabib and Spiegel (1994), secondary education is crucial when it comes to technology diffusion. Aghion and Howitt (1992) argue that secondary education tends to favor imitation-type catch up, whereas tertiary 
education favors innovation. Hence, we interact the catching-up term with secondary rather than tertiary education, and keep tertiary education as a separate term. ${ }^{47}$ We estimate the following relation, again on five-year intervals due to the periodicity of education data:

$\ln \left(\frac{A_{i, t}}{\mathrm{~A}_{\mathrm{i}, \mathrm{t}-1}}\right)=\alpha_{0, r}+\alpha_{1} a_{i, t-1}+\alpha_{2} h_{i, t-1}^{3}+\alpha_{3} a_{i, t-1}\left(h_{i, t-1}^{2}-h_{i, t-1}^{3}\right)+\epsilon_{j, t}$

where $A_{i, t}$ denotes the TFP of country $i$ in year $t, a_{i, t-1}=\ln \left(\frac{A_{i, t-1}}{A_{t-1}^{*}}\right)$ represents the distance to the TFP frontier $A^{*}$ in year $t-1,{ }^{48} h_{j, t-1}^{3}$ is the proportion of the working-age population with a tertiary diploma, $h_{j, t-1}^{2}-h_{j, t-1}^{3}$ is the proportion of the working-age population with a secondary diploma but no tertiary one, and $\alpha_{0, r}$ is a regional fixed effect. We expect $\alpha_{1}<0$ (TFP growth is lower when country $i$ is closer to the frontier), $\alpha_{2}>0$ (more tertiary education is beneficial to innovation), and $\alpha_{3}<0$ (more secondary education tends to reduce the negative effect of being closer to the TFP frontier). To circumvent endogeneity problems, we use lagged values of $a_{i, t-1}, h_{i, t-1}^{3}, a_{i, t-1}\left(h_{i, t-1}^{2}-\right.$ $\left.h_{i, t-1}^{3}\right), a_{i, t-1} h_{i, t-1}^{2}, \quad a_{i, t-1} h_{i, t-1}^{3}$ (i.e. twice-lagged variables) as our five instrumental variables, in line with the literature. ${ }^{49}$ Finally, we follow Vandenbussche in using region-specific effects that are based jointly on geographical and income criteria. We therefore use our geographical zones in conjunction with the World Bank classification of income levels (High- $(\mathrm{H})$, Medium- $(\mathrm{M})$ and Low-

\footnotetext{
47 Introducing the interaction between secondary education and distance to TFP leader in the formulation by Vandenbussche et al. (2006) would mathematically imply the addition of a "secondary and more" term, but preliminary tests showed that this term was not significant.

The TFP frontier is made of the five highest TFP countries. The composition of this group varies over time within the following list: the USA, Denmark, Germany, Norway, Sweden, France, the Netherlands, Belgium, Ireland, and Iceland (we excluded Luxembourg and Switzerland as outliers). In the projection exercise, each country reaching the group of the five best performers at least once is applied the average, $0.995 \%$ TFP growth rate of the TFP frontier of the 1995-2008 period. Hence, the technological frontier includes more and more countries over time.

${ }^{49}$ See Vandenbussche et al. (2006). In order to select our specification, we follow the methodology and tests proposed by Baum, C.; Schaffer, M. \& S. Stillman, (2003), 'Instrumental variables and GMM: Estimation and testing', Stata Journal 3(1), 1-31. We first run the Durbin-Wu-Hausman joint-endogeneity test, which rejects, at the 5 percent confidence level, the null of joint exogeneity of secondary education, tertiary education and distance to frontier. Regarding instrumentation, our goodness-of-fit tests suggest that these instruments are relevant (they are correlated with the instrumented variables), and the different validity tests performed all fail to reject the null of orthogonality at the 5\% confidence level, hence confirming the orthogonality of the instruments with the error terms. The results from these different tests are available from the authors.
} 
(L) income). We then need to cluster the residuals by country. The results are reported in Table B.3. All coefficients are significant at the 5 percent level, with expected signs. Ceteris paribus, being 10 percent below the TFP frontier induces a 0.1 percent extra growth of TFP, for a median level of secondary education. In turn, a rise of tertiary education by 10 percentage points raises TFP growth by 0.5 percentage points.

Table B. 3 - TFP estimation results

\begin{tabular}{lc}
\hline Dependent variable: TFP growth & $(1)$ \\
\hline Distance to the TFP frontier & $-0.0154 * * *$ \\
& $(0.005)$ \\
Tertiary education & $0.0537^{* * *}$ \\
& $(0.019)$ \\
Distance to frontier×secondary & $-0.0137 * * *$ \\
education & $(0.005)$ \\
\hline Hansen J-stat & 3.565 \\
(p-value) & $(0.168)$ \\
No. Obs. & 650 \\
No. clusters & 132 \\
\hline Standard errors in parentheses. $* \mathrm{p}<0.1, * * \mathrm{p}<0.05, * * * \mathrm{p}<0.01$. \\
Note: 5-year intervals \\
Source: own calculations.
\end{tabular}

\section{d. Savings rate}

Following Masson, Bayoumi and Samiei's (1998), we specify the saving rate as a function of the agestructure of the population and on the GDP-per-capita gap with the leading economy. To summarize the age structure with a few variables, we use the methodology proposed by Higgins (1998): denoting by $j(j=1, \ldots, J)$ each cohort of the population $(0-4,5-9, \ldots, 65-69$ and $70+)$ and $p_{j}$ its proportion in the population, we define each demographic variable $d^{k}(k=1, \ldots, K)$ as follows:

$d^{k}=\left(\sum_{j=1}^{J} j^{k} p_{j}-\frac{1}{J} \sum_{j=1}^{J} j^{k}\right)$

The number of demographic variables $(K)$ is determined by an Akaike information criterion. It is set to three here. The estimated equation then: 


$$
\left(\frac{S}{Y}\right)_{i, t}=\alpha_{i}+\beta_{1} \frac{y_{i, t-1}}{y_{U S, t-1}}+\beta_{2}\left[\frac{y_{i, t-1}}{y_{U S, t-1}}\right]^{2}+\beta_{3} g_{i, t-1}+\sum_{k=1}^{K} \varphi_{k} d_{i, t}^{k}+\sum_{k=1}^{K} \eta_{k} d_{i, t}^{k} \cdot g_{i, t-1}+\varepsilon_{i, t}
$$

where $(S / Y)_{i, t}$ denotes the saving rate in country $i$ at time $t$ (5-year average), $y_{i, t}$ is country $i$ 's per capita GDP, $g_{i, t}$ is the rate of growth of per capita GDP, ${ }^{50}$ and the variables $d_{i, t}^{k}$ are demographic factors constructed as follows (for simplicity, country and year subscripts are dropped):

The behaviour underpinning Equation (B.5) is structural. However it may omit important determinants of savings rates, such as institutions, governance or culture, which move only slowly, hence cannot be introduced in a panel regression. Covering these factors would require a pluridisciplinary approach that is beyond the scope of this paper. We then assume constant institutions that are embodied in the country fixed effects.

The econometric results are presented in Table B. 4. An increase in per capita GDP relative to the US, or a higher per capita GDP growth rate, implies a rise in the savings rate. In terms of the demographic factors, only their interaction with growth has a significant impact on the savings rate. Hence our preferred specification is the one in Column (2) of Table B.4, where additive demographic factors are dropped, as well as the non-linear term in GDP per capita.

\footnotetext{
${ }^{50}$ Both per capita GDP and its growth rate are lagged so that the equation can be used non-recursively in a projection exercise.
} 
Table B. 4 - Determinants of the savings rate, estimation results

Dependent variable: saving rate

Lagged GDP per cap. rel. to the USA

(1)

(2)

$0.205^{* * *}$

$0.121^{* * *}$

(0.055) (0.019)

Lagged squared GDP per cap. rel. to the

USA

$-0.013$

$(0.011)$

Lagged GDP per cap. growth

$\begin{array}{cc}1.007 * * * & 1.139 * * * \\ (0.284) & (0.237)\end{array}$

Demography $d^{1}$

0.218

(0.196)

Demography $d^{2}$

$-0.015$

$(0.033)$

Demography $d^{3}$

$-0.000$

$(0.002)$

$d^{1}$ x GDP per cap. growth

$-13.068 * * * \quad-12.074 * * *$

(3.739)

(3.203)

$d^{2}$ x GDP per cap. growth

$2.253 * * *$

$2.149 * * *$

(0.611)

(0.521)

$d^{3} \mathrm{x}$ GDP per cap. growth

$-0.102 * * * \quad-0.099 * * *$

(0.027)

(0.023)

Constant

$0.035 \quad 0.140 * * *$

(0.029) (0.006)

$\mathrm{N}$

929

929

R-sq.

0.172

0.152

Standard errors in parentheses; ${ }^{*} \mathrm{p}<0.1,{ }^{* *} \mathrm{p}<0.05, * * * \mathrm{p}<0.01$

Note : 5-year averages

Source: own calculations. 
e. Savings and investment (panel cointegration tests)

Tables B.5 and B.6 report various panel cointegration tests for the OECD and non-OECD samples. Pedroni's tests use a null hypothesis of no cointegration, both for homogenous or heterogeneous panels. Among these tests, four have an alternative hypothesis of a homogenous cointegration relation ("within", which are panel- $v$, panel- $\rho$, panel-PP and panel-ADF) and the three other have an alternative hypothesis of heterogenous cointegration ("between", which are group- $\rho$, group-PP and group-ADF). Westerlund tests are second-generation tests, with a null hypothesis of no cointegration for all countries. Ga and Gt statistics operate in panel context, with an alternative hypothesis of cointegration for at least one country. On the contrary, $\mathrm{Pa}$ and $\mathrm{Pt}$ operate on pooled data, and the alternative hypothesis of the test is that there is cointegration for all individuals. The difference between the "a" and " $\mathrm{t}$ " tests is that they respectively use weighted average of the ECM coefficients and t-ratios respectively.

The conclusion of these tests is straightforward: we are in front of two cointegrated variables for which we may assume homogenous cointegration relation (within each group). Note that these tests do not infer anything about the possibility of fixed effects in the estimated cointegration relations. 
Table B. 5 - Cointegration tests for the OECD group

\begin{tabular}{l|llllll}
\hline Author & Name & $\mathrm{H}_{0}$ & \multicolumn{1}{c}{$\mathrm{H}_{\mathrm{a}}$} & Statistic & $\mathrm{p}$-value & $5 \%$ test \\
\hline \multirow{3}{*}{$\begin{array}{l}\text { Pedroni } \\
\text { (13 countries })\end{array}$} & Panel- $v$ & No coint. & All homogenous coint. & -0.937 & 0.826 & × \\
& panel- $\rho$ & No coint. & All homogenous coint. & -2.247 & 0.012 & $\checkmark$ \\
& panel-PP & No coint. & All homogenous coint. & -4.201 & 0.000 & $\checkmark$ \\
& Panel-ADF & No coint. & All homogenous coint. & -5.239 & 0.000 & $\checkmark$ \\
& group- $\rho$ & No coint. & All heterogenous coint. & 0.049 & 0.519 & $x$ \\
& group-PP & No coint. & All heterogenous coint. & -2.388 & 0.008 & $\checkmark$ \\
& group-ADF & No coint. & All heterogenous coint. & -4.932 & 0.000 & $\checkmark$ \\
\multirow{5}{*}{ Westerlund } & $\mathrm{Ga}$ & No coint. & At least 1 coint. & -7.600 & 0.000 & $\checkmark$ \\
& $\mathrm{Gt}$ & No coint. & At least 1 coint. & -1.847 & 0.000 & $\checkmark$ \\
& $\mathrm{Pa}$ & No coint. & All heterogenous coint. & -9.048 & 0.000 & $\checkmark$ \\
& $\mathrm{Pt}$ & No coint. & All heterogenous coint. & -4.862 & 0.000 & $\checkmark$
\end{tabular}

Source: own calculations.

Table B. 6 - Cointegration tests for the non-OECD group

\begin{tabular}{l|llllll}
\hline Author & Name & $\mathrm{H}_{0}$ & $\mathrm{H}_{\mathrm{a}}$ & Statistic & p-value & $5 \%$ test \\
\hline \multirow{3}{*}{$\begin{array}{l}\text { Pedroni } \\
\text { (37 countries) }\end{array}$} & Panel- $v$ & No coint. & All homogenous coint. & -1.323 & 0.9072 & $\mathbf{x}$ \\
& panel- $\rho$ & No coint. & All homogenous coint. & -4.561 & 0.0000 & $\checkmark$ \\
& panel-PP & No coint. & All homogenous coint. & -5.551 & 0.0000 & $\checkmark$ \\
& Panel-ADF & No coint. & All homogenous coint. & -7.376 & 0.0000 & $\checkmark$ \\
& group- $\rho$ & No coint. & All heterogenous coint. & -1.612 & 0.0534 & x \\
& group-PP & No coint. & All heterogenous coint. & -6.310 & 0.0000 & $\checkmark$ \\
& group-ADF & No coint. & All heterogenous coint. & -8.304 & 0.0000 & $\checkmark$ \\
\multirow{5}{*}{ Westerlund } & $\mathrm{Ga}$ & No coint. & At least 1 coint. & -4.660 & 0.019 & $\checkmark$ \\
& $\mathrm{Gt}$ & No coint. & At least 1 coint. & -1.186 & 0.013 & $\checkmark$ \\
& $\mathrm{Pa}$ & No coint. & All heterogenous coint. & -4.358 & 0.000 & $\checkmark$ \\
& $\mathrm{Pt}$ & No coint. & All heterogenous coint. & -5.070 & 0.000 & $\checkmark$
\end{tabular}

Source: own calculations 